INVITED REVIEW- Cell Tissue Research

Maternal adaptations and inheritance in the transgenerational programming of adult disease

Linda A. Gallo ${ }^{1}$, Melanie Tran ${ }^{1}$, Jordanna S. Master ${ }^{1}$, Karen M. Moritz ${ }^{2}$ and Mary E. Wlodek ${ }^{1}$

${ }^{1}$ Department of Physiology, The University of Melbourne, Parkville VIC Australia;

${ }^{2}$ School of Biomedical Sciences, University of Queensland, St Lucia QLD Australia.

Corresponding Author:

Assoc Prof Mary Wlodek

Department of Physiology

The University of Melbourne

Parkville, Victoria 3010

Australia

Telephone: $\quad+61383448801$

Fax: $\quad+61383445818$

email: $\quad$ m.wlodek@unimelb.edu.au 


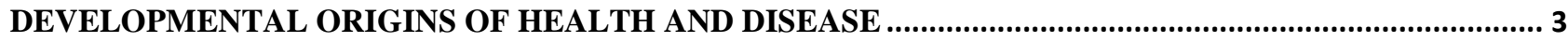

DEVELOPMENTAL ORIGINS OF CARDIOVASCULAR AND KIDNEY DISEASE ..................................................... 4

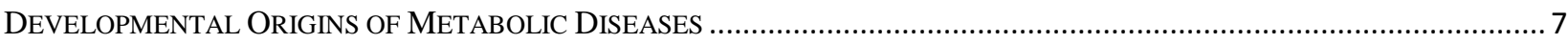

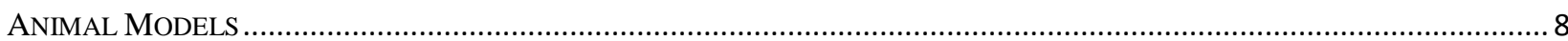

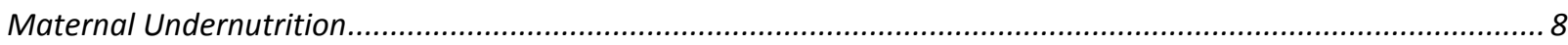

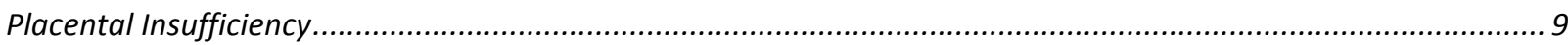

PROGRAMMING CONSEQUENCES FOR FEMALES BORN SMALL......................................................13

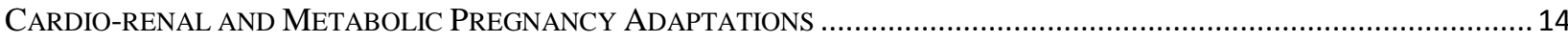

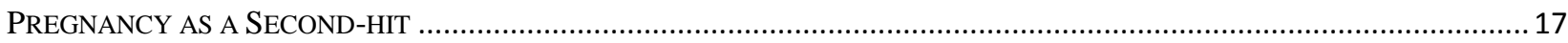

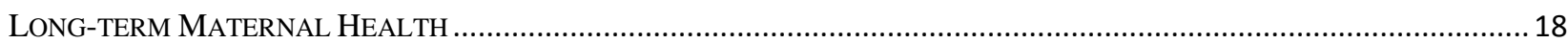

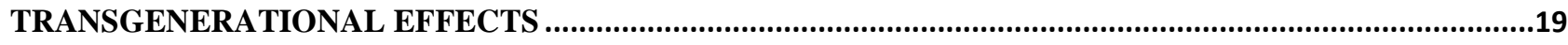

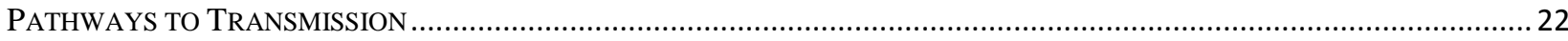

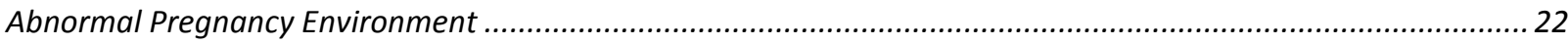

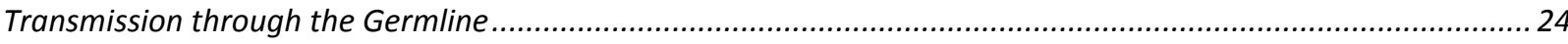

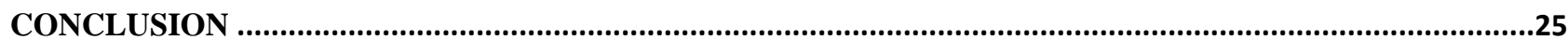


Adverse exposures in utero have long been linked with an increased susceptibility to adult cardiorenal and metabolic diseases. Clear gender differences exist, whereby growth restricted females, although exhibiting some phenotypic modifications, are often protected from overt disease outcomes. One of the greatest physiological challenges facing the female gender however is that of pregnancy, yet little research has focused on the outcomes associated with this, as a potential 'second-hit' for those who were small at birth. We review the limited evidence suggesting that pregnancy may unmask cardio-renal and metabolic disease states and the consequences for longterm maternal health in females who were born small. Additionally, a growing area of research in this programming field is in the transgenerational transmission of low birth weight and disease susceptibility. Pathways for transmission might include an abnormal adaptation to pregnancy by the growth restricted mother and/or inheritance via the parental germline. Strategies to optimise the pregnancy environment and/or prevent the consequences of inheritance of programmed deficits and dysfunction are of critical importance for future generations. 


\section{Developmental Origins of Health and Disease}

More than two decades ago, David Barker proposed that developmental insults during critical intrauterine or early postnatal periods program an increased susceptibility to developing a myriad of adult-onset diseases (Barker et al. 1989a;Barker et al. 1990;Hales et al. 1991). Strong epidemiologic evidence for an association between low weight at birth and increased incidence of adult cardiovascular and metabolic diseases were the basis for this developmental origins of health and disease hypothesis. Recent work in both humans and animal models support these findings, with additional evidence for a developmental origin of kidney disease (Hoy et al. 1999).

The human fetus can respond to an adverse intrauterine environment by altering its growth and developmental patterns (Bateson et al. 2004;Gluckman et al. 2005;Hales and Barker 1992; Lucas 1991). In order to enhance immediate survival under poor in utero conditions, the growth of key body organs, particularly the brain, is protected at the detriment of others (Hales and Barker 1992). Offspring physiology is permanently altered and this 'thrifty phenotype hypothesis' suggests that in utero adaptations become unfavourable when postnatal nutrition is affluent (Hales and Barker 1992). Lucas' 'programming' definition further proposes that adaptations induced during sensitive developmental periods serve as predictive responses of postnatal life (Lucas 1991). More recently, the term 'developmental plasticity' is employed and describes a variety of phenotypes that result from a single genotype in response to different environmental stimuli (Barker 2004). This phrase also offers an intergenerational perspective, such that primary alterations are maintained and perpetuated across generations via non-genetic or heritable mechanisms (Drake and Walker 2004;Bateson et al. 2004). Used interchangeably, these terms link the development of adult disease to adverse conditions in utero that is typically marked by a low weight at birth.

Low birth weight is defined as weighing less than the $10^{\text {th }}$ percentile for gestational age (or $<2.5 \mathrm{~kg}$ at term) and occurs in $\sim 10 \%$ of pregnancies worldwide (Berghella 2007; Martin et al. 2007). Maternal stressors such as malnutrition, hypoxia, glucocorticoids, smoking and alcohol consumption are associated with fetal growth restriction and have serious implications for later offspring health (Granger 2002;Berghella 2007). Furthermore, spontaneous pregnancy complications such as inadequate trophoblast invasion prevent maximal dilation of uteroplacental arteries, increased resistance and reduced nutrient and oxygen delivery to the fetus (Wu et al. 2006). While maternal undernutrition is responsible for the majority of fetal growth restriction in developing countries, uteroplacental insufficiency is of considerable concern to the Western world and becomes most apparent during the third trimester when fetal demands are at their greatest (Henriksen and Clausen 2002).

Growth restricted infants often experience 'catch-up' growth where weight is restored towards their genetic growth trajectory by late childhood (McMillen and Robinson 
2005;Albertsson-Wikland et al. 1998). Such accelerated growth however is independently associated with an increased risk of developing a range of adult diseases (Eriksson et al. 2000). Eriksson and colleagues reported that an accelerated growth from birth to seven years of age amplified the risk of adult hypertension in men and women born small, and growth beyond seven years was associated with the development of type 2 diabetes (Eriksson et al. 2000). Further studies identified that low weight gain before, and rapid weight gain after one year of age increased the incidence of coronary heart disease in men that were thin at birth (Eriksson et al. 2001). Early catch-up growth before one year of age may therefore protect against the adverse effects of low birth weight through an adaptive response to increased demand, while weight gain in later childhood, upon restricted cell numbers and limited plasticity, is likely to exhaust overall function. It has been suggested that childhood weight gain following restricted growth in utero may be an evolutionary advantage to buy survival at least until reproductive age (McMillen and Robinson 2005). Indeed, the timing of such catch-up growth appears to be a critical determinant for long-term health.

While recent reviews have focused on the evidence for developmental origins of adult cardiovascular, kidney and metabolic diseases, including the disparity between males and females in disease risk and the tissue systems affected, we extend our review to include the physiological constraints of the growth restricted female, particularly with regard to her pregnancy outcome and long-term maternal health. Furthermore, we review the role of the maternal environment $v s$ inheritance (and their interactions) in the transfer of disease risk to a subsequent generation.

\section{Developmental Origins of Cardiovascular and Kidney Disease}

The inverse relationship between birth weight and cardiovascular disease risk has been well documented across a range of human populations. Studies by Barker and colleagues are routinely carried out in well developed, well-nourished settings across the United Kingdom (Barker et al. 1989a;Barker et al. 1990;Barker et al. 1989b;Osmond et al. 1993;Law et al. 1993), while others are in pregnant women exposed to undernutrition, such as during the Dutch hunger winter (Painter et al. 2005). Despite widespread famine, women continued to conceive and give birth, such that the trimesters of pregnancy to which the fetus was exposed were able to be separated (Ravelli et al. 1998). This provided a unique opportunity to identify the organ systems affected by perturbations during specific developmental periods. It was found that adults whose mothers were exposed to famine during first trimester had increased rates of coronary heart disease and alterations to clotting factors compared with those exposed during late gestation or not at all. Those from mothers exposed during mid gestation showed increased risk of microalbuminuria, while those exposed in late gestation were more likely to experience glucose intolerance (Roseboom et al. 2001). The 
mechanisms pertaining to disease development however may differ by initial cause, and caution should be exercised upon review of various populations.

One of the first studies in the United Kingdom involved 5,654 men born during 1911-30 that were traced throughout their lives (Barker et al. 1989a). Men with the lowest weights at birth had the greatest death rates from ischemic heart disease and it was proposed that measures to increase prenatal growth should be employed. A similar study was concurrently carried out in over 5,000 women born during 1923-30 and the highest death rates from cardiovascular disease were among those born of below-average weight; the association weaker than seen in men (Osmond et al. 1993). Since these early findings, a range of studies have been carried out observing the relationship between birth weight and cardiovascular disease risk factors such as hypertension. A study in both men and women aged 46-54 years, showed a strong inverse association between weight at birth and blood pressure (Barker et al. 1990). Furthermore, Law and colleagues found that for every kilogram decrease in birth weight, systolic blood pressure increased by $5.2 \mathrm{mmHg}$ in $64-71$ year old British men and women and the strength of this relation increased with age (Law et al. 1993). Even at 10 years of age, systolic blood pressure has been shown to increase by $0.38 \mathrm{mmHg}$ and $1.32 \mathrm{mmHg}$ in British boys and girls, respectively, who were born of the lowest weights (Barker et al. 1989b).

Albeit less studied, similar associations between birth weight and renal disease (defined by a range of measures) have been noted. A comprehensive systematic review and meta-analysis of 32 observational studies across Europe, Australia, North America and Asia found that low birth weight was strongly and significantly associated with a $70 \%$ increased risk of chronic kidney disease compared with individuals born of normal weight (White et al. 2009). Glomerular filtration rate (GFR) estimates based on serum creatinine measures were performed across all reviewed studies and the magnitude of association was consistent for chronic kidney disease whether defined as albuminuria, low GFR or end-stage renal disease (obtained from dialysis and transplant registries). Heterogeneity in disease definitions however prevented joint estimates of the effect of incremental changes of birth weight on kidney function and adjustments for age, sex, ethnicity, socioeconomic status, parental factors, blood pressure and diabetes were inconsistent across the studies.

On review of the original studies, a Norwegian group reported that young adults born small for gestational age had low kidney function (reduced creatinine clearance) and for every kilogram increase in birth weight, creatinine clearance increased by $7.2 \mathrm{ml} / \mathrm{min}$ and $5.7 \mathrm{ml} / \mathrm{min}$ in men and women, respectively (Hallan et al. 2008). An alternate study, included in the abovementioned metaanalysis, showed that American men, but not women, born of low weight had a greater incidence of chronic kidney disease, defined as low GFR or elevated urine albumin/creatinine ratio at 18-75 years of age (Li et al. 2008). Birth weights however were self-reported and there were no records of gestational age. Nevertheless, a report comprising data obtained from medical birth registries 
support an increased incidence of end-stage renal disease (Norwegian Renal Registry) in those with birth weights $<10^{\text {th }}$ percentile compared to weights in the $90^{\text {th }}$ percentile and once corrected for gestational age, this association was also only significant in men (Vikse et al. 2008). Interestingly, the relative risk for end-stage renal disease in those born of the lowest weights was greater during the first 14 years of life compared with those between 15 and 38 years of age. It is likely however that any deficits established in utero had a greater impact beyond 38 years, upon exhaustion of early compensatory responses.

The prevalence of hypertension and chronic kidney disease for African Americans and Aborigines is much greater than white subjects in the U.S. and Australia, respectively (Hughson et al. 2003; Hughson et al. 2006; Hoy et al. 2006). Although likely to be mediated through malnutrition, numerous autopsy studies have been carried out in these populations to determine the factors associated with increased rates of disease. Amongst infant, child and adult African Americans, birth weight was directly and strongly correlated with nephron number and an estimate of $>250,000$ nephrons for every kilogram increase in birth weight was predicted (Hughson et al. 2003). However, in 2006 a follow-up study reported no association between blood pressure, nephron number and birth weight in African Americans but did in white subjects (Hughson et al. 2006). Despite nephron number being lower in hypertensive African Americans, it was suggested that a doubling of the sample size would be required for the difference to approach statistical significance. Strong correlations between adult height, nephron number and blood pressure have also been reported in Australian Aborigines, just as low nephron number is associated with increased susceptibility to renal failure (Hoy et al. 2006).

Since no new nephrons are formed after birth in humans, prenatal development is absolutely critical in determining final nephron endowment. Studies have shown a strong direct correlation between nephron number and birth weight, and a strong inverse relationship between glomerular volume and birth weight (Manalich et al. 2000). Similarly, Hinchliffe and colleagues showed that growth restricted stillborns had reduced nephron number when compared to those weighing above the $90^{\text {th }}$ percentile (Hinchliffe et al. 1992). Furthermore, growth restricted infants that died within one year of a life birth showed reduced nephron number but no difference in nephron volume, indicating no early postnatal compensation. It was suggested that elective preterm therapy should be considered for affected fetuses in order to redeem renal development prior to the loss of the nephrogenic zone (Hinchliffe et al. 1992). Indeed, this has implications for other developing organ systems and consideration must be given to their critical developmental stages. 


\section{Developmental Origins of Metabolic Diseases}

The link between low weight at birth and the subsequent development of type 2 diabetes was first reported by Hales and colleagues in over 300 men from Hertfordshire, U.K. (Hales and Barker 1992; Hales et al. 1991). A standard oral glucose challenge was performed to identify men with diabetes (plasma glucose $>11.1 \mathrm{mmol} / \mathrm{l}$ ) or the precursor disorder, impaired glucose tolerance (plasma glucose $7.8-11.0 \mathrm{mmol} / \mathrm{l}$ ). Hales reported that among men in their $60 \mathrm{~s}$, those who had low weight at birth and at 1 year of age were more likely to develop impaired glucose tolerance and type 2 diabetes (Hales et al. 1991). The study was repeated in a cohort of both men and women residing in Preston, U.K. and the prevalence of type 2 diabetes and impaired glucose tolerance fell with increasing birth weight; $27 \%$ in those weighing $<2.5 \mathrm{~kg}$ at birth to $6 \%$ in those weighing $>3.4 \mathrm{~kg}$ after adjusting for current body mass index (Phipps et al. 1993). Other epidemiologic studies have supported the association between weight at birth and the prevalence of impaired glucose tolerance, type 2 diabetes and metabolic syndrome (McCance et al. 1994;Lithell et al. 1996;Phillips et al. 1994;Phillips 1996). Furthermore, small placental size and increased placental to birth weight ratio is associated with impaired glucose tolerance and insulin sensitivity (Barker et al. 2001).

The importance of maternal nutrition on offspring growth and development is well supported by a number of post-war follow-up studies, most noteworthy being the Dutch hunger winter (Roseboom et al. 2001;Ravelli et al. 1998). Maternal severe undernutrition during mid or late gestation resulted in babies born lighter, shorter and thinner with smaller heads and placentas than those conceived either before or after the famine (Roseboom et al. 2001). As adults, these offspring were more likely to develop impaired glucose tolerance and obesity (Ravelli et al. 1976;Ravelli et al. 1998). In contrast, a study on 37 males and 132 females born during the Leningrad siege of 1941-1944 showed no relationship between maternal dietary intake and metabolic disease risk (Stanner and Yudkin 2001). Importantly, poor nutrition extended into the early postnatal years, in contrast to the Dutch hunger winter where it became plentiful within 3 weeks. This suggests that predictive adaptive responses occur by the fetus to maximise uptake of available nutrients resulting in conserved metabolism after the Leningrad siege; the in utero response may have been appropriate for the postnatal environment. This is in contrast to the Dutch hunger winter, as intrauterine malnutrition had an adverse impact when postnatal nutrition became sufficient.

There are limited investigations into organ-specific effects associated with programmed metabolic pathologies in humans. In intrauterine growth restricted newborn infants who died within 48 hours after birth, islet vasculature and the percentage of islet and $\beta$-cell densities were significantly lower than in those born of normal weight (Van Assche et al. 1977). Muscle insulin resistance has been implicated as a potential contributor, associated with reduced expression of various insulin signalling proteins and a failure to up-regulate skeletal muscle and adipose tissue 
GLUT4 gene expression following insulin stimulation (Ozanne et al. 2005; Jaquet et al. 2001). Furthermore, insulin-stimulated whole body glycolysis and muscle glucose uptake was reduced in 19 year old men with low weight at birth compared with those born of normal weight (Jensen et al. 2002; Hermann et al. 2003). As the skeletal muscle is the primary site for insulin stimulated glucose utilization, the defects in the expression of insulin signalling molecules may underlie or contribute to muscle insulin resistance resulting in impaired glucose tolerance. Other metabolic organs including the pancreas and liver however have not been specifically investigated in human studies despite a likely role.

\section{Animal Models}

Animals have been used in highly controlled, well-designed settings to investigate the underlying mechanisms between birth weight, cardiovascular, kidney and metabolic outcomes. A range of species are used in the manipulation of the maternal environment, including mice, guinea pigs and baboons and to a greater extent, sheep and rats. Research has focused on maternal exposure during specific gestational periods to a range of insults including glucocorticoids, hypoxia, smoking and alcohol, while those of interest to this review, being responsible for the majority of human low birth weight, are maternal undernutrition and uteroplacental insufficiency.

\section{Maternal Undernutrition}

Low birth weight can be induced by total caloric restriction (equal reductions of all nutrients) or specific nutrient deficiencies (low protein, iron and sodium) (Garofano et al. 1997;Hill and Duvillie 2000;Snoeck et al. 1990;Fernandez-Twinn et al. 2003). Models of different nutritional insults at different stages of gestation and/or after birth produce variable postnatal outcomes. Woods and colleagues reported that maternal protein restriction during all of pregnancy was associated with a $25 \%$ reduction in nephron number, $16 \%$ reduction in GFR and $10 \mathrm{mmHg}$ increase in conscious blood pressure in 21 week old growth restricted male rat offspring (Woods et al. 2001). Furthermore, a recent study reported that both pre- and postnatal protein restriction reduced nephron number, estimated renal plasma flow (eRPF) and GFR in male rat offspring at 4-5 weeks of age but blood pressure surprisingly decreased (Hoppe et al. 2007). An alternate study using maternal low sodium in the last 7 days of rat pregnancy, reported increasing trends for blood pressure in 12 week old offspring but no difference in nephron number during fetal, early postnatal or adult life (Battista et al. 2002). Finally, Holemans et al., reported no difference in blood pressure in adult female rat offspring exposed to global maternal undernutrition during the second half of gestation (Holemans et al. 1999). 
In terms of metabolic health, rat offspring exposed to an $8 \%$ dietary protein deprivation throughout gestation had reduced $\beta$-cell mass and islet size (Snoeck et al. 1990;Dahri et al. 1991). When offspring were provided with a normal postnatal diet, islet morphology recovered, but if the protein deficiency extended to weaning, these modifications were irreversible. These studies provide evidence for maternal influences on fetal islet development, but also that the neonatal period exhibits developmental plasticity that may be specifically targeted to offset disease. Further studies on male rat offspring of mothers who were subjected to a low protein diet during pregnancy showed clear age-dependent changes in glucose control. In early life, glucose tolerance was increased and plasma insulin concentrations reduced, indicating increased insulin sensitivity that was absent by one year of age (Ozanne et al. 1998). At 15 months of age, offspring developed impaired glucose tolerance (Ozanne et al. 2003) and by 17 months frank diabetes was evident (Petry et al. 2001). Plasma insulin concentrations also doubled, clearly indicating insulin resistance at this age (Ozanne et al. 2003). Reductions in total caloric intake throughout pregnancy however differentially affect fetal pancreas development compared with protein deprivation. When severe calorie restriction (50\% restriction) was imposed on day 15 of pregnancy in Wistar rats, $\beta$-cell mass and insulin content were significantly decreased from birth (Garofano et al. 1997). Despite improved nutrition after birth and evidence of catch up growth by weaning, $\beta$-cell mass and insulin content remained low, and in fact worsened with age (Garofano et al. 1997). Garofano suggested that dietary restriction during the weaning period is most detrimental to the development of pancreatic insulin status, while others have clearly shown that severe early restriction (70\%) results in altered fetal plasma insulin levels and pancreatic structure and function (Woodall et al. 1996). Periconceptional maternal undernutrition studies in sheep however have shown slowed fetal growth and impaired glucose tolerance in adult offspring (Rumball et al. 2009;Todd et al. 2009) that might be mediated by impaired maternal insulin-related metabolism (Jaquiery et al. 2009). Indeed, differences in species, timing and type of nutrient restriction play a significant role in determining future health outcomes, but challenge the ability to interpret and collate the broad array of animal data. A review by Armitage et al. showed that two diets with the same amount of protein actually contained different sources of calories supporting that differences in diet composition are likely to contribute to the variable findings (Armitage et al. 2005).

\section{Placental Insufficiency}

Placental insufficiency is responsible for the majority of intrauterine growth restriction in developed countries and its induction in both sheep and rats have been extensively published. In sheep, removal of placentation sites prior to pregnancy or umbilical-placental embolization is performed during late gestation. These growth restricted fetuses exhibit a $24 \%$ reduction in nephron number 
(Zohdi et al. 2007), delayed cardiomyocyte maturation and increased vasoconstrictor responsiveness in coronary arteries at embryonic day 130 (term 147 days) (Bubb et al. 2007). In placentally restricted fetal sheep, males but not females, had reduced $\beta$-cell mass, and plasma insulin and glucose concentrations, whilst glucose stimulated insulin disposition was enhanced (Robinson et al. 1979;Gatford et al. 2008). Alternate studies have subsequently shown that aged male sheep develop fasting hypoinsulinaemia and impaired glucose tolerance (De Blasio et al. 2007; Owens et al. 2007). Surprisingly, $\beta$-cell mass was up-regulated in the adult male with increased hepatic but reduced skeletal muscle insulin sensitivity (Gatford et al. 2008). This might suggest plasticity of the pancreas and liver to attempt to compensate for the impaired insulin secretion and skeletal muscle insulin resistance.

First developed by Wigglesworth et al., ligation of the uterine blood vessels during late gestation in rats perturbs uteroplacental nutrient and oxygen perfusion, and compromises fetal growth and development (Wigglesworth 1974). Offspring birth weight is reduced by 10-15\% compared with sham operated counterparts and is comparable to the magnitude of growth restriction seen in human populations (Wlodek et al. 2005;Simmons et al. 2001). This model is often characterised by asymmetric growth restriction (brain sparing) and incomplete postnatal catch-up growth. Growth restricted rat offspring consistently present with reduced nephron number throughout life and often develop elevated blood pressure by adulthood (Wlodek et al. 2008;Alexander 2003). Previously, Sanders and colleagues reported a 30\% nephron deficit at postnatal day 21 in male rat offspring exposed to uterine artery ligation, which was associated with renal hyperfiltration and elevated urinary albumin excretion at 12 weeks of age (Sanders et al. 2004). At this young age, the increase in glomerular size is likely to have protected renal function; supported by the normal plasma creatinine levels and mean arterial pressure. By 22 weeks of age, we reported a $9 \mathrm{mmHg}$ increase in systolic blood pressure, associated with reduced nephron endowment (-27\%) and concomitant glomerular hypertrophy in growth restricted male offspring (Wlodek et al. 2008). However, when these growth restricted males were cross-fostered onto a control mother from postnatal day 1 , milk quality and offspring growth were improved and blood pressure and nephron number were unaffected (nephrogenesis continues 2 weeks postnatally in rats) (Wlodek et al. 2007). This highlights the postnatal plastic potential in altricial species such as rats, which would reflect late gestational stages in precocial species such as humans. In a later study by our group, growth restricted female offspring, cross-fostered onto a dam that underwent the ligation surgery, also presented with reduced nephron number from 6 months but compensatory glomerular hypertrophy did not occur until 18 months of age (Moritz et al. 2009). Although plasma creatinine levels were elevated in these growth restricted females, blood pressure remained normal even at 18 months. 
Despite some evidence for an association between low nephron number and elevated blood pressure (Wlodek et al. 2007; Vehaskari et al. 2001), a large amount of data suggests otherwise (Sanders et al. 2004;Zimanyi et al. 2004). In an attempt to explain this phenomenon, Moritz and Bertram proposed that there are potential 'modifiers' that determine the final outcome in face of prenatal perturbations (Moritz and Bertram 2006). The timing and severity of the initial insult, as well as offspring genetics and postnatal growth, play a critical role in determining whether a nephron under-endowment leads to the development of adult hypertension. In addition, rather than low nephron number per se solely contributing to elevated blood pressure, compensatory alterations such as glomerular hypertrophy and eventual glomerulosclerosis may be important determinants. In the study by the Sanders et al., despite reduced nephron number and compensatory glomerular hypertrophy, there was no evidence of glomerulosclerosis at the young age (Sanders et al. 2004). Indeed, glomerular damage is likely to ensue with chronic hyperfiltration and thus impair kidney function and elevate systemic blood pressure in the long-term. However, we have recently reported elevated blood pressure in low birth weight male rat offspring, but no alterations in the mRNA markers of glomerulosclerosis, including collagen 1 and 3, MMP2, MMP9, TIMP1, TIMP2 or TGF$\beta$ (Wlodek et al. 2008). Although kidney tissue sections were not precisely examined for glomerulosclerosis, no obvious pathological signs were detected during glomerular counting. Accordingly, it is possible that rather than glomerulosclerosis preceding hypertension, the development of hypertension itself may contribute to glomerulosclerosis, setting up a cycle that further elevates blood pressure. This is supported by a maternal low protein study that reported elevated blood pressure in 8 week old growth restricted rat offspring, with no evidence of glomerulosclerosis until 18 months of age (Vehaskari et al. 2001). This suggests other modifiers might be involved for the initial development of hypertension associated with low birth weight and deficits in nephron number.

It has been proposed that low nephron number is adequately compensated for, until a postnatal stressor (second-hit) pushes the kidney to its absolute limit and reveals a clinically relevant symptom (Nenov et al. 2000). This may explain variable findings in the association between nephron number and blood pressure, including why some adults can donate a kidney and never develop hypertension (Najarian et al. 1992;Ramcharan and Matas 2002). In support of this, rat offspring exposed to low protein during gestation and fed a high-salt diet during adulthood had greater increases in arterial blood pressure than offspring fed a normal salt diet postnatally (Woods et al. 2004) and ageing was linked with worsened hypertension in rat offspring exposed to a low protein diet from mid-gestation with reduced nephron endowment (Vehaskari et al. 2001).

Additionally, others have shown that uteroplacental insufficiency is associated with impaired glucose tolerance and reduced insulin secretion and sensitivity by 15 weeks of age in male 
rat offspring (Simmons et al. 2001;Nusken et al. 2008). By 26 weeks of age, these growth restricted rats were markedly diabetic and obese, and $\beta$-cell mass was less than one third that of controls. Further studies identified that this $\beta$-cell deficit was associated epigenetic silencing of the key transcription factor, Pdx-1 (Park et al. 2008). This severe phenotype may be attributable, in part, to the susceptibility of the Sprague Dawley rat strain to metabolic disorders (Barzilai and Rossetti 1995). We have reported similar findings however in non-obese, growth restricted Wistar Kyoto males that were hyperglycemic and hyperinsulinemic at 24 weeks of age (Wadley et al. 2008;Siebel et al. 2008). This was associated with a 40-45\% reduction in pancreatic $\beta$-cell mass, which was importantly rescued with improved postnatal nutrition (cross-foster approach) or treadmill exercise training early or later in life (Siebel et al. 2010;Laker et al. 2011). In contrast, our growth restricted females were not hyperglycemic, nor hyperinsulinemic despite similar pancreatic-specific changes such as reduced fed basal insulin secretion and a 36\% decrease in $\beta$-cell mass. Of interest, a secondhit of a high fat diet for growth restricted offspring (induced by hypoxia) resulted in elevated fat deposition which was associated with significant impairments in lipid profiles and glucose homeostasis (Rueda-Clausen et al. 2011).

The metabolic capacities of the skeletal muscle and liver may also be compromised by poor developmental conditions. Impaired glucose tolerance in growth restricted individuals is associated with alterations in peripheral and hepatic insulin signalling and glucose uptake (Shulman 2000). Insulin-stimulated glucose entry into the skeletal muscle occurs via the glucose transporter GLUT4 (Dugani and Klip 2005). In the growth restricted rat, fetal skeletal muscle total GLUT4 expression is decreased, but the amount bound to the plasma membrane is increased. The diminished intracellular stores suggests a compensatory adaptation to low glucose availability during fetal life (Thamotharan et al. 2005). In the adult rat however, skeletal muscle GLUT4 was increased on the plasma membrane but translocation of additional GLUT4 in response to insulin was diminished. Impaired insulin sensitivity also contributes to the development of diabetes and impaired glucose tolerance with males particularly affected. Reduced skeletal muscle insulin sensitivity may be a result of reduced insulin receptor protein, elevated PCG-1 mRNA and protein and reduced expression of enzymes important for long chain fatty acid formation and oxidation (Lane et al. 2002). Additionally, insulin is unable to fully suppress hepatic glucose production and as a result, hepatic gluconeogenesis is increased in adult growth restricted male rats (Vuguin 2007). The reduced hepatic insulin sensitivity may be caused by increased expression of PPAR $\gamma$ coactivator-1 protein, a regulator of mRNA expression of glucose-6-phosphate and other gluconeogenesis enzymes in the intrauterine growth restricted rat liver (Lane et al. 1996; Lane et al. 2002). This suggests that alterations in hepatic glucose production may be the result of changes in intracellular signalling. Furthermore, Camm and colleagues showed that prenatal hypoxia, independent of 
nutrient restriction, was associated with a downregulation of a number of insulin signalling proteins in adult rat muscle and liver (Camm et al. 2011). Developmental perturbations are associated with changes in the structure and intracellular signalling of the pancreatic islets, skeletal muscle and liver. The final outcome of these alterations is decreased insulin secretory capacity despite an increase in demand, leading to the development of impaired glucose tolerance and diabetes later in life.

\section{Programming Consequences for Females Born Small}

As previously mentioned, some researchers have identified exacerbated outcomes associated with postnatal 'second-hits' in those born small including the male gender, high fat/salt diets, lack of exercise and ageing. If however we consider one of the greatest challenges faced to women, we can hypothesise that pregnancy represents a profound physiological demand that may serve to unmask various disease states (see Figure 1). Given that many women will, at some point during their reproductive years, become pregnant it is surprising that very little consideration has gone into the pregnancy outcomes experienced by those who were small at birth. Here, we briefly review the intricate physiological state of pregnancy including cardio-renal and metabolic changes that are essential to support the growth and development of the fetus (Granger 2002;Torgersen and Curran 2006). Additionally, we review the limited evidence that, while the majority of pregnancy-related changes are physiological and reversed after parturition, sub-clinical diseases may emerge and in fact persist in the long-term, particularly for those who were small at birth. Importantly, adverse pregnancy adaptations for female offspring born small can have implications of the development of the next generation. 


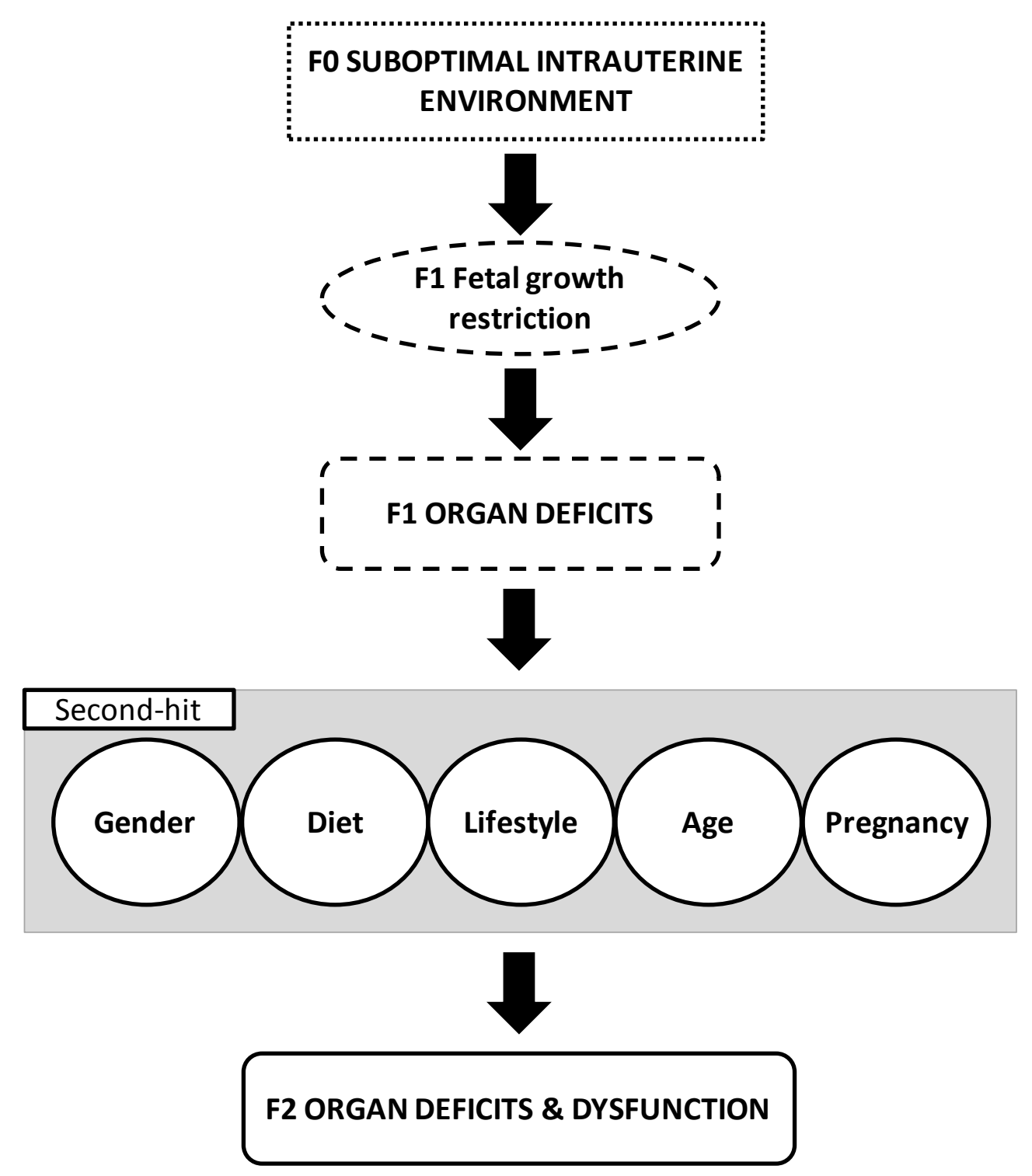

Figure 1 Second-hit reveals F2 dysfunction

A suboptimal intrauterine environment in the (F0) mother programs first generation (F1) organ deficits for offspring born small. Second-hit factors including male gender, poor diet, adverse lifestyle choices, aging and pregnancy may exacerbate the growth restriction phenotype of organ deficits and reveal dysfunction and disease in offspring born small. $\mathrm{F} 0=\operatorname{dot} ; \mathrm{F} 1=$ dash; $\mathrm{F} 2=$ solid.

\section{Cardio-renal and Metabolic Pregnancy Adaptations}

Pregnancy is often regarded as a hyperdynamic, hypervolemic and low resistance state (Torgersen and Curran 2006). By late pregnancy, maternal blood volume expands by up to $50 \%$ in humans and $30 \%$ in rats to enable optimal perfusion and oxygenation of vital tissues and the developing fetus (Atherton et al. 1982;Hill and Pickinpaugh 2008;Granger 2002;Torgersen and Curran 2006). There is a larger increase in plasma volume relative to erythrocyte volume, resulting in haemodilution and physiological anemia (Hill and Pickinpaugh 2008). Cardiac output increases by up to 50\% and heart 
rate increases by $15-20$ beats per minute by third trimester (Yeomans and Gilstrap, III 2005; Torgersen and Curran 2006). Studies in rats have reported reduced baroreceptor activity during pregnancy that allows for expansion in plasma volume (Hines 2000). Blood perfusion to the uterus (20-25\% of maternal cardiac output), maternal kidneys (20\% of maternal cardiac output), extremities, breasts and skin all increase at the expense of splanchnic bed and skeletal muscle blood flow (Hill and Pickinpaugh 2008; Metcalf et al. 1955). The hypervolemic state is secondary to a $15 \%$ reduction in peripheral vascular tone, restoring the initial drop in systemic blood pressure by term (Clark et al. 1989; Hill and Pickinpaugh 2008; Granger 2002; Torgersen and Curran 2006).

Progesterone and relaxin are likely responsible for the vasodilator response at pregnancy onset (Davison 1985; Torgersen and Curran 2006). Since diastolic blood pressure tends to decrease more than systolic blood pressure (Torgersen and Curran 2006), the pregnant woman is predisposed to edema and varicose veins (Hill and Pickinpaugh 2008). Increased fetal heat production also contributes to reduced vascular resistance, particularly in the extremities (Torgersen and Curran 2006). Despite increased levels of circulating renin during pregnancy, the woman is resistant to the pressor effects of Angiotensin II and blood pressure does not increase (Luppi 1999). This may be due to increased nitric oxide production during pregnancy, antagonising the vasoactive effects of Angiotensin II and noradrenalin (Rosenfeld 2001). Elevated renin however acts on the kidneys to retain sodium and water contributing to plasma volume expansion (Luppi 1999).

Dilation of renal vasculature soon after conception permits greater blood flow to the maternal kidneys (Lindheimer et al. 2001). By mid human pregnancy, GFR and eRPF increase by 40-65\% and 50-85\%, respectively compared with pre-pregnant and postpartum values (Lindheimer et al. 2001; Granger 2002). In pregnant rats, GFR and eRPF increases are smaller at 20-40\% above normal (Granger 2002). Since increases in eRPF are often greater than GFR, the filtration fraction (GFR/eRPF) is reduced (Yeomans and Gilstrap, III 2005). Renal hyperfiltration is associated with increased urine flow and volume, as well as elevated creatinine, urea, uric acid and glucose clearance (Torgersen and Curran 2006). Marked increases in GFR may result in proteinuria, particularly in a pregnancy complicated by maternal hypertension and/or preeclampsia. In turn, increased solute filtration reduces plasma osmolality and viscosity, considered to aid uteroplacental perfusion. Many factors mediate the changes in renal hyperaemia during pregnancy. Elevated renal expression of nitric oxide synthase (NOS) is evident and inhibition of NOS isoforms have been shown to blunt renal hyperfiltration (Danielson and Conrad 1995;Gandley et al. 2001). Furthermore, the peptide hormone relaxin has been implicated in playing a critical role in renal vasodilation and hyperfiltration (Danielson et al. 2000).

Glucose is the primary energy source for fetal and placental growth and maternal metabolic responses are altered to meet these demands (Herrera 2000; Nolan and Proietto 1994). Despite 
increased gluconeogenic activity, glucose is the most abundant substrate able to cross the placenta and is partially responsible for the maternal hypoglycemia seen during late gestation (Butte 2000; Herrera 2000). In addition, liver glycogen stores become depleted and contribute to the fall in blood glucose concentration. This hypoglycaemic state is apparent despite increased insulin resistance by maternal tissues (Herrera 2000). The exact mechanisms pertaining to the insulin resistant state of pregnancy is unknown but in vivo studies have shown that pregnant rats become progressively resistant, probably due to the constitutive availability of insulin (Leturque et al. 1984a;Leturque et al. 1984b;Knopp et al. 1970b). Compensatory increases in insulin synthesis and secretion peak around mid gestation, partly attributed to increased $\beta$-cell division (proliferation) and size (hypertrophy) which doubles $\beta$-cell mass by term (Fowden and Hill 2001;Blondeau et al. 1999;Kawai and Kishi 1999). Glucose is the major impetus for $\beta$-cell compensation during pregnancy, so the transient hyperglycemia in response to diminished insulin sensitivity may mediate this structural and functional adaptation in the pancreas (Butte 2000). Furthermore, the considerably greater secretory response of pancreatic $\beta$-cells relative to maternal blood glucose in normal pregnancy indicates an overall increased sensitization to the effects of glucose (Bone and Taylor 1976; Leturque et al. 1984a; Kawai and Kishi 1999). These adaptive and reversible changes within the pancreatic islets are thought to be mediated by placental lactogen and/or prolactin (Bell and Bauman 1997).

Lipid metabolism is also altered during pregnancy, with accumulation of fat deposits and increased plasma cholesterol and triglyceride concentrations (Hytten and Leitch 1971;Lopez-Luna et al. 1986;Merzouk et al. 2000). Additionally, hyperlipidemia corresponds to an increase in plasma triglycerides during late pregnancy as a result of enhanced adipose tissue lipogenesis (Huda et al. 2009;Knopp et al. 1970a). The first two thirds of pregnancy reflect an anabolic state, whereby maternal fat stores are accumulated in response to increased nutrient storage and hyperphagia (Lopez-Luna et al. 1986; Villar et al. 1992). In the last third of pregnancy, fetal growth and development is accelerated, sustained by enhanced placental transfer of nutrients and the mother switches to a catabolic state (Knopp et al. 1970a;Butte 2000).

Skeletal muscle is the primary site of glucose disposal and along with the liver, it also becomes resistant to insulin during the latter half of pregnancy (Bell and Bauman 1997). This is accompanied by decreased glucose uptake in peripheral tissues and increased hepatic glucose output. Skeletal muscle insulin resistance is balanced by a sustained state of hyperinsulinaemia that maintains normal glucose homeostasis. The precise mechanisms underlying skeletal muscle insulin resistance are unknown but may involve alterations in the early stages of insulin action. These include changes in expression and action of the insulin receptor, insulin receptor substrate-1 (IRS-1) and PI-3-kinase. Upon insulin stimulation in pregnant rats, Saad and colleagues found that there 
were no significant effects on insulin receptor levels in rat liver and muscle (Saad et al. 1997). Despite normal numbers, there was a 30-36\% reduction in the autophosphorylation of IR in the liver and skeletal muscle, consistent with reductions in IRS-1 and PI-3-kinase protein levels.

\section{Pregnancy as a Second-hit}

Pre-pregnancy disease or increased susceptibility to disease may become exacerbated during pregnancy as maternal and fetal demands increase. Certainly, this may compromise the acute and long-term health of the mother, as well as the developing offspring. A recent population-based study in Norway reported that women with elevated blood pressure and reduced GFR antedating pregnancy were at increased risk of developing preeclampsia and giving birth to preterm or small for date infants (Munkhaugen et al. 2009). It was found that $15 \%$ of women within reproductive age have a mild decrease in GFR and thus early identification and treatment of renal insufficiency is critical in the prevention of adverse pregnancy outcomes. In addition, women with chronic kidney disease are at $37 \%$ increased risk for delivering a low birth weight offspring (Jones and Hayslett 1996), and others concluded that chronic kidney disease was associated with preeclampsia, preterm delivery, chronic hypertension and worsening renal function during pregnancy (Ramin et al. 2006).

Klebanoff and colleagues reported that small birth weight women were more likely to develop hypertension during pregnancy, after 20 weeks' gestation, compared with those born of normal weight (Klebanoff et al. 1999). Pregnancy induced hypertension in those born small showed a stronger association than that for preterm women and was independent of their mothers' own gestational blood pressure. In addition, others have reported that being born small for gestational age markedly increases the risk of severe preeclampsia, independent of exposure to preeclampsia in the previous generation (Zetterström et al. 2007). Reduced nephron number and/or alterations in maternal vascular remodelling may mediate gestational hypertension and proteinuria in women who were born small. In healthy rats however, Baylis and colleagues reported equal relaxation of afferent and efferent arterioles during pregnancy, thus keeping glomerular pressure constant and unlikely to cause morphological damage (Baylis 1994). This supported a previous study also in healthy rats showing no blood pressure or renal pathology following five successive pregnancies (Baylis and Rennke 1985). Indeed, cardio-renal health during pregnancy may be determined by a pre-existing susceptibility. We have recently found however, that despite previous reports of nephron deficits and vascular dysfunction in non-pregnant rats (Anderson et al. 2006; Moritz et al. 2009; Mazzuca et al. 2010), females have normal blood pressure and no overt renal pathologies during late pregnancy (Gallo et al. 2012). Although pregnancy was associated with the emergence of glomerular hypertrophy at an earlier age (4 months) than previously reported in 18 month old virgin females (Moritz et al. 2009), this may reflect perfect adaptation to maintain optimal function 
during pregnancy. Additionally, the same cohort of growth restricted pregnant females exhibited rescued uterine artery stiffness compared with virgin counterparts (Mazzuca et al. 2009a); an adaptive response to maintain uteroplacental blood perfusion. Thus, growth restricted female rats show at 4 months of age mostly normal cardio-renal function during pregnancy. Increased maternal age and obesity however, reflective of current Western trends, may reveal an adverse cardio-renal phenotype in those who were born small.

Gestational diabetes mellitus affects 3-7\% of all pregnancies and is defined by any degree of impaired glucose tolerance. Insufficient pancreatic insulin response relative to the insulin resistant state of pregnancy is a major contributor to glucose intolerance (Kuhl 1991; Van Assche et al. 2001) and is associated with an increased risk of developing type 2 diabetes in later life (Feig et al. 2008;Retnakaran et al. 2008;Retnakaran 2009). Thus, an adverse pregnancy adaptation may accelerate the development of type 2 diabetes in susceptible women (Sattar 2004) and a strong inverse relationship has been shown between a woman's own birth weight and her subsequent risk for gestational diabetes mellitus (Seghieri et al. 2002). We have recently reported that in response to a glucose load, plasma glucose concentration in growth restricted pregnant females does not lower to the same magnitude as controls (Gallo et al. 2012). This loss of glucose tolerance was sustained to at least 90 minutes post-glucose injection, despite a normal plasma insulin response. Future maternal risk of developing diabetes and cardiovascular disease is directly proportional to the degree of gestational dysglycemia (Carr et al. 2008;Retnakaran 2009), such that growth restricted females who develop even mild gestational glucose intolerance are at increased risk later in life. Furthermore, given the adverse effects of maternal obesity on glucose metabolism during pregnancy and excess weight gain after pregnancy (Gunderson et al. 2004;Huda et al. 2009; Sathyapalan et al. 2009), exposing our growth restricted females to high-fat feeding is likely to reveal and exacerbate a cardio-renal and metabolic disease phenotype during and after pregnancy.

\section{Long-term Maternal Health}

While the majority of pregnancy adaptations are transitory and fully reversed after delivery, some alterations have been shown to persist in the long-term. A study in humans found that blood pressure was, on average, $2 \mathrm{mmHg}$ lower in parous compared with non-parous women 20 years post-pregnancy (Gunderson et al. 2008). This difference between groups was suggested to be mediated by pregnancy-induced vascular endothelial changes but it was noted that pregnancy may simply define a group of women with better cardiovascular function. Specifically, the long-term health of a mother following a complicated pregnancy has been an area of much research. Pregnancy induced hypertension is associated with maternal hypertension and microalbuminuria seven years post pregnancy (Nissel et al. 1995) and is a risk factor for cardiovascular disease at 40 
years follow-up (Garovic et al. 2010). Furthermore, women with a history of preeclampsia have an increased risk of developing kidney and cardiovascular diseases (Vikse et al. 2008;Bellamy et al. 2007). Those women who experienced gestational diabetes in at least one pregnancy have a $30 \%$ increased risk of developing type 2 diabetes and a 2-2.4 fold increased risk of metabolic syndrome in later life (Sathyapalan et al. 2009;Gunderson et al. 2009). Women who delivered a low birth weight infant also present with elevated blood pressure and have increased incidence of ischaemic heart disease and maternal death from coronary heart disease in the long term (Walker et al. 1998;Smith et al. 2001;Friedlander et al. 2007). Finally, maternal life span is reduced following a pregnancy complicated by preeclampsia, preterm delivery or fetal growth restriction (Irgens et al. 2001; Lykke et al. 2010).

The mechanisms underlying these outcomes are not fully understood but such pregnancy complications may trigger permanent vascular and metabolic disruptions leading to future disease states. For example, markers of endothelial dysfunction have been shown to remain elevated more than 15 years following a pregnancy complicated by preeclampsia (Sattar et al. 2003). It is important to note that maternal birth weights are rarely reported in follow-up pregnancy studies and thus the contribution of a previous developmental insult compared with a spontaneous complication in their own pregnancy is unknown. It is likely that the physiological stress of pregnancy reveals an underlying predisposition to disease in females who were themselves born small and provides an indication to future health outcomes. This has further implications for subsequent generations, whereby maternal and/or paternal disease states set up a cycle of continued growth and development perturbations with consequences for programmed diseases.

\section{Transgenerational Effects}

Much evidence supports that adverse conditions in utero are not merely limited to affect the first, directly exposed generation, but can have transgenerational effects. Several follow-up studies from the Dutch hunger winter provide compelling evidence that maternal exposures can have permanent life-long effects on offspring health that are perpetuated across generations (Heijmans et al. 2008). Women who were undernourished in utero during the famine delivered smaller babies that went on to develop a range of adult-onset diseases including hypertension, cardiovascular disease, impaired glucose tolerance and obesity (Roseboom et al. 2001). Additionally, the British National Child Development Study showed programmed effects on birth weight in the third generation (F3) through the maternal line (Alberman et al. 1992;Emanuel et al. 1992), while Kaati and colleagues showed transmission of cardiovascular disease and diabetes from grandparents who were exposed to low food availability during their childhood to F2 offspring via the paternal line (Kaati et al. 2002). Transmission might occur via direct exposure of F1 germ cells to the initial insult; termed 
multigenerational effects. Alternative, or indeed concurrent hypotheses, are true intergenerational inheritance through persistent epigenetic modifications of either parental germ cells and/or abnormal pregnancy adaptations (see Figure 2). The two latter studies however suggest that programmed outcomes are passed to an unexposed generation via intergenerational inheritance, and that both maternal and paternal lines play a role.

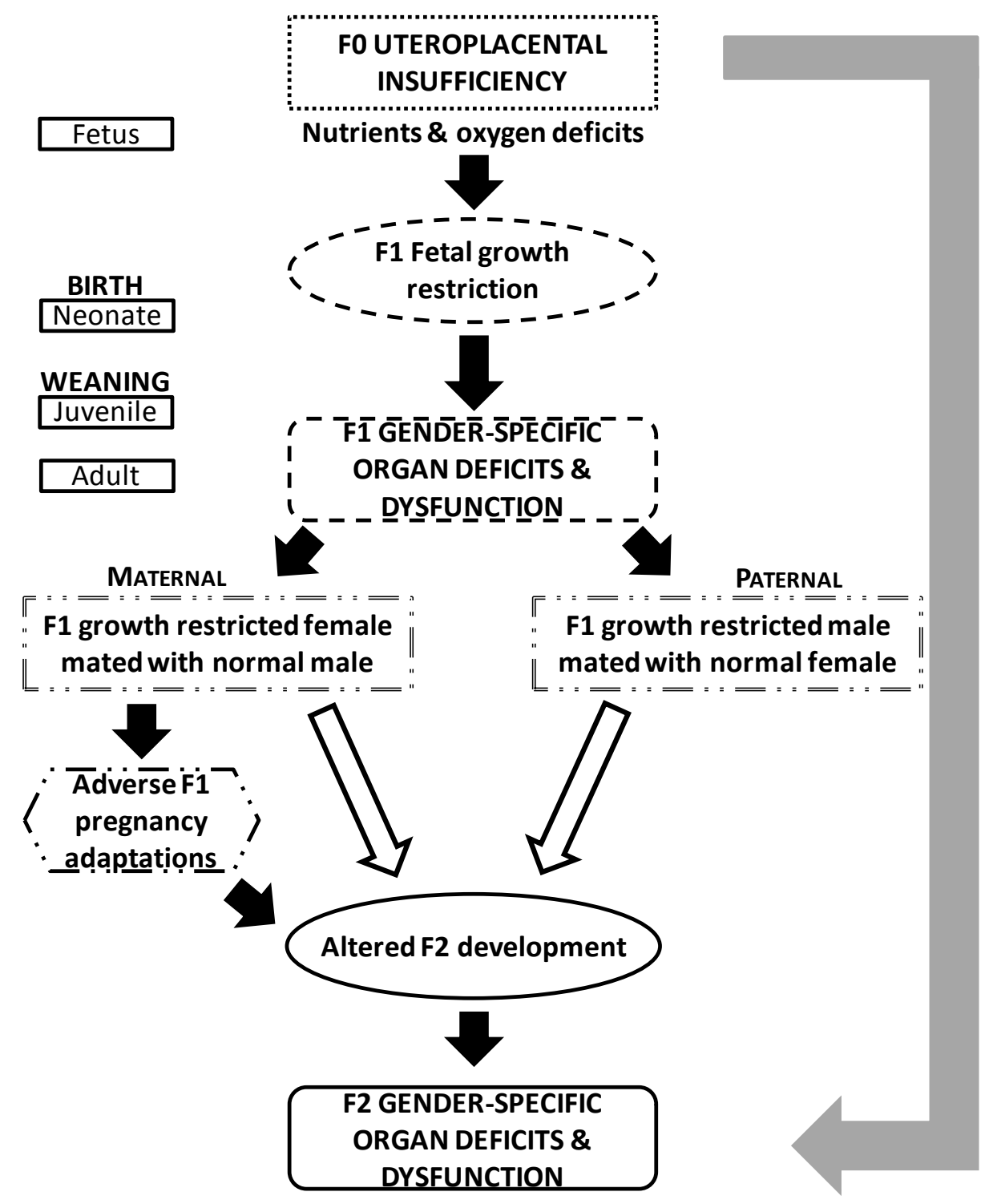

Figure 2 Transgenerational programming

Uteroplacental insufficiency (F0) programs first generation (F1) fetal growth restriction, and gender-specific organ deficits and dysfunction. These can be transmitted to second generation (F2) offspring via direct exposure of F1 germ cells to the initial insult; termed multigenerational effects, true intergenerational inheritance through persistent epigenetic modifications of either parental germ cells and/or abnormal pregnancy adaptations. F0 = dot; F1= dash; F1 mothers or fathers $=$ dot dash; F2 = solid; grey arrow = multigenerational; open arrows = intergenerational. 
Animal models also provide evidence for transgenerational programming of various disease phenotypes. Torrens and colleagues showed for the first time, in a rat model of maternal low protein throughout gestation, transmission of hypertension and endothelial dysfunction of the high resistance mesenteric bed to F2 offspring via the maternal line (Torrens et al. 2008). Bertram et al. also investigated the transgenerational effects of nutrient restriction during early or late pregnancy on cardiovascular parameters and hypothalamo-pituitary-adrenal function in guinea pigs (Bertram et al. 2008). They found that F1 females exposed to food restriction early, but not late, in gestation delivered F2 males with adult-onset hypertension and increased left ventricular wall thickness and mass. On the other hand, basal cortisol levels were elevated, with alterations to HPA responsiveness in F2 offspring from dams exposed to late-gestation nutrient restriction. This may have mediated, in part, the transgenerational growth restriction observed in F2 offspring from late-gestation nutrient restricted dams. These data support evidence from the Dutch hunger winter, whereby fetal growth was reduced only in those exposed to famine during late gestation (Painter et al. 2005). This suggests that fetal growth is not a sole predictor of programmed effects, and is rather an adaptive attempt that cannot always be correlated with prenatal exposures. Others have subsequently reported elevated blood pressure and reduced nephron number in two rat generations, with the F2 phenotype coming from either the mother or the father's prenatal exposure to low protein with no additive effects (Harrison and Langley-Evans 2009). There were no effects on the F3 generation suggesting that the initial insult had a multigenerational impact on the F1 fetus and the germ cells that form the F2 generation. This is contrary to the human work noted above, whereby disease transmission occurred in an unexposed generation (Alberman et al. 1992;Emanuel et al. 1992;Kaati et al. 2002). Transmission of cardiovascular dysfunction has also been reported in a rat model of preeclampsia, whereby reduced uterine perfusion pressure in experimental dams resulted in elevated blood pressure and vasoconstrictor hyperesponsiveness in two subsequent generations (Anderson et al. 2006).

Others have also shown altered glucose and insulin metabolism of male and female F2 offspring whose mothers were exposed to low protein during gestation (Zambrano et al. 2005). This occurred in a timed- and sex-specific manner, whereby insulin resistance was evident in F2 males from mothers exposed to low protein during lactation and F2 females from mothers exposed to low protein during gestation. Furthermore, in a maternal global caloric restriction study, reduced birth weight was transmitted to the second generation and, via the paternal line, these offspring developed impaired glucose tolerance and $\beta$-cell dysfunction (Jimenez-Chillaron et al 2009). On the other hand, obesity was transmitted via the maternal line, demonstrating that metabolic pathologies may be predicted by the parental line affected. In an alternate study, growth restricted females with 
impaired pancreas development subsequently delivered macrosomic male offspring (Frantz et al. 2011) which is a common diabetogenic effect; the U-shaped relationship between birth weight and later metabolic disease risk. F2 and F3 male offspring however had reduced relative pancreas weight at birth, with reduced islet volume and $\beta$-cell mass at postnatal days 1 and 21 , and were hypoinsulinemic at day 21. Effects in the third generation suggest intergenerational transmission of metabolic disease risk factors through mechanisms other than direct exposure to gametes. Others support these findings, where effects on glucose metabolism were extended to the third generation (Benyshek et al. 2006). Indeed, transmission of altered metabolism appears to be associated with a maternal diabetogenic effect. Dexamethasone exposure during pregnancy has also been implicated in the transmission of low birth weight and development of impaired glucose tolerance in F2 male offspring via both parental lines (Drake et al. 2005). These effects were not associated with glucose intolerance in F1 males and maternal glucose tolerance was not assessed. Furthermore, there were no effects in the third generation. Many transgenerational studies to date have not considered nor explored adverse maternal pregnancy adaptations that may have occurred and their consequences to next generation offspring health.

Recently, we have shown in our rat model of uterine vessel ligation that F1 females develop some loss of glucose tolerance during late pregnancy but exhibit normal uterine artery relaxation (Gallo et al. 2012;Mazzuca et al. 2009b). This was associated with a 5-6\% reduction in F2 male and female fetal weight compared with those from normal birth weight controls. Interestingly however, F2 fetal weight was not affected in those from growth restricted females that were not exposed to environmental stressors during late pregnancy (i.e. metabolic cage, tail-cuff blood pressure and glucose tolerance tests). This recent finding may be supported by several studies that have associated prenatal maternal stress or cortisol treatment to offspring low birth weight (Lazinski et al. 2008). Furthermore, pregnant rats exposed to chronic stress do not show normal elevations in placental 11 $\beta$-HSD2 activity in order to prevent maternal to fetal cortisol transfer upon acute stress (Welberg et al. 2005). Our data suggest that maternal stress played an additive role in unmasking the transmission of low birth weight and may have implications for future health and disease.

\section{Pathways to Transmission}

\section{Abnormal Pregnancy Environment}

Underlying mechanisms in the transgenerational programming of low birth weight, cardio-renal and metabolic pathologies have received some attention in recent years. Maternal weight at birth, prepregnancy weight and weight gain during pregnancy are responsible for $10 \%$ of the variance in determining fetal weight, while fathers' birth weight is responsible for only 3\% (Berghella 2007). 
We reported that growth restricted female rats catch up at mating and weight gain during pregnancy is similar to controls (Gallo et al. 2012). Thus, F2 fetal growth restriction in our model is unlikely to be influenced by maternal, nor paternal, weight. However, growth restricted females develop some loss of glucose tolerance and glomerular hypertrophy during pregnancy which is likely to influence the next generation (Gallo et al. 2012). Nevertheless, human studies have reported that short women give birth to smaller babies (Ramakrishnan et al. 1999;Cawley et al. 1954) and reduced uterine and ovarian size is evident in females who were small at birth (Ibanez 2000).

In addition to anatomical constraints, disrupted cardiovascular, metabolic and endocrine responses have been implicated in mediating much of the transgenerational effects associated with developmental programming. Specifically, maternal raised blood pressure, hyperglycemia and excess glucocorticoids have the potential to adversely affect fetal development. Maternal hypertension is associated with the delivery of small-for-date infants (Buchbinder et al. 2002) and gestational diabetes has been linked with increased risk of diabetes and obesity in human offspring (Dabelea et al. 2000). Studies in mice have reported hypertension, microalbuminuria and impaired glucose tolerance in offspring exposed to maternal diabetes (Chen et al. 2010) and female diabetic offspring of rats treated with streptozotocin during pregnancy deliver F2 offspring with altered glucose metabolism (Oh et al. 1991). We have shown that maternal exposure to physiological stressors during late pregnancy was an additive factor, in combination with low maternal birth weight and loss of glucose tolerance, in the transmission of F2 fetal growth restriction in rats (Gallo et al. 2012). Rat models of maternal nutrient restriction have shown altered vascular responses during an F1 pregnancy (Torrens et al. 2003;Hemmings et al. 2005) that may have long-term consequences for the F2 generation. Offspring born to hypertensive NOS3 knockout mice have increased sensitivity to vasoconstrictors, impaired endothelium-dependent vasodilation and hypertension (Constantine et al. 2008). We have recently shown however that increased uterine artery stiffness observed in non-pregnant growth restricted female rats is resolved in late pregnancy (Mazzuca et al. 2009a). When and how this presumably beneficial adaptation takes place remains to be elucidated, as increased vascular stiffness during early gestation cannot be excluded as a potential mediator of adverse F2 outcomes.

Animal studies suggest that mother-to-offspring disease transmission may involve somatic epigenetic modifications. Epigenetic modifications involve heritable changes in gene function that are not mediated by changes in DNA sequence. These might include chromatin remodelling (DNA methylation and histone modification) and non-coding RNA and microRNA modifications that are usually established early in development but may occur in response to environmental cues later in life. Alterations in maternal behaviour were associated with epigenetic modifications of the estrogen receptor ER $\alpha 1 \mathrm{~b}$ promoter and ER expression in brain tissue of female rat offspring and 
transmitted down generations (Champagne et al. 2006). Thus, transgenerational transmission may occur through epigenetic modifications to somatic tissues, in response to alterations in maternal physiology and behaviour.

\section{Transmission through the Germline}

Evidence for a paternal role in the transmission of programmed phenotypes raises the possibility of an alternate route of transmission; epigenetic modifications transmitted through the germline. Female germline transmission may also occur, either independently or in addition to the somatic effects of an abnormal uterine environment. Rat embryo transfer studies have investigated this, whereby an F2 female conceived by a nutrient-and growth restricted F1 mother was transferred into a control mother (Thamotharan et al. 2007). It was reported that the transgenerational transmission of impaired glucose metabolism was independent of the uterine environment and thus mediated through the germline.

During normal development, inherited epigenetic information in germ cells is usually erased and re-set to ensure totipotency. Epigenetic erasure and re-establishment occurs again, postfertilisation at non-imprinted genes. Often, these modifications escape reprogramming and some ancestral marks are inherited in the next generation (Jablonka and Raz 2009). Many programming models have described epigenetic modifications in offspring exposed to placental insufficiency and maternal nutrient restriction (Fu et al. 2004;Park et al. 2008; Pham et al. 2003). Recent work has also shown altered methylation and histone acetylation of specific gene promoters in a maternal protein restriction rat model that was transmitted to the F2 generation (Burdge et al. 2007). Female ooycte development in mammals is complete at birth and male sperm precursor cells are present from fetal life. Thus, prenatal insults have the capacity to interrupt the reprogramming process of germ cells and their precursors that go on to form the F2 generation, termed direct induction (Jablonka and Raz 2009). An alternate mode of transmission is through somatic induction, whereby insults to the F1 fetus induce epigenetic modifications in germ cells (Jablonka and Raz 2009). These modes of transgenerational programming however suggest effects are limited to first and second generation offspring only; unless epigenetic marks escape another bout of reprogramming in the germline and post-fertilisation. This would then describe true epigenetic inheritance, whereby stable modifications in germ cells are transmitted from one generation to the next via the gametes (Jablonka and Raz 2009). In the case of exposing a pregnant F0 female to an adverse agent, three generations of inheritance would be required to confirm epigenetic inheritance while in males, two generations are sufficient. 


\section{Conclusion}

The contribution of adverse fetal exposures to the susceptibility and development of adult cardiorenal and metabolic diseases is apparent. While growth restricted females are often protected from overt disease outcomes, emerging evidence indicates an inherent susceptibility to abnormal pregnancy adaptations. Furthermore, the physiological stress associated with pregnancy in females that were born small may unmask or accelerate future disease risk. Susceptible females should therefore be closely monitored during and after their pregnancy for targeted prevention strategies.

Finally, abnormal pregnancy adaptations may be associated with the transgenerational transmission of low weight at birth and disease development in subsequent generation(s). This may be mediated by epigenetic somatic modifications, and/or (given the evidence for paternally-derived effects) through the germline. The established technique of embryo transfer can allow us to identify the contribution of an abnormal maternal environment $v s$ inherited mechanisms. If evidence directs towards the former, strategies to optimise the pregnancy environment will be of critical importance for the mother and her progeny over generations. On the contrary, if inherited mechanisms consistently come of light, in combination with reported paternal effects, mechanisms underlying heritable programming of disease should be of key focus for future investigations. 


\section{References}

Alberman E, Emanuel I, Filakti H, Evans SJ (1992) The contrasting effects of parental birthweight and gestational age on the birthweight of offspring. Paediatr Perinat Epidemiol 6:134-144

Albertsson-Wikland K, Boguszewski M, Karlberg J (1998) Children born small-for-gestational age: postnatal growth and hormonal status. Horm Res 49:7-13

Alexander BT (2003) Intrauterine growth restriction and reduced glomerular number: role of apoptosis. Am J Physiol 285:R933-R934

Anderson CM, Lopez F, Zimmer A, Benoit JN (2006) Placental insufficiency leads to developmental hypertension and mesenteric artery dysfunction in two generations of SpragueDawley rat offspring. Biol Reprod 74:538-544

Armitage JA, Taylor PD, Poston L (2005) Experimental models of developmental programming: consequences of exposure to an energy rich diet during development. J Physiol 565:3-8

Atherton JC, Dark JM, Garland HO, Morgan MR, Pidgeon J, Soni S (1982) Changes in water and electrolyte balance, plasma volume and composition during pregnancy in the rat. J Physiol 330:8193

Barker DJ, Bull AR, Osmond C, Simmonds SJ (1990) Fetal and placental size and risk of hypertension in adult life. Br Med J 301:259-262

Barker DJ, Winter PD, Osmond C, Margetts B, Simmonds SJ (1989a) Weight in infancy and death from ischaemic heart disease. Lancet 2:577-580

Barker DJP (2004) The developmental origins of adult disease. J Am Coll Nutr 23:558S-595S

Barker DJP, Forsén T, Uutela A, Osmond C, Erickson JG (2001) Size at birth and resilience to effects of poor living conditions in adult life: longitudinal study. Br Med J1273

Barker DJP, Osmond C, Golding J, Kuh D, Wadsworth MEJ (1989b) Growth in utero, blood pressure in childhood and adult life, and mortality from cardiovascular disease. Br Med J 298:564567

Barzilai N, Rossetti L (1995) Relationship between changes in body composition and insulin responsiveness in models of the aging rat. Am J Physiol 269:E591-E597

Bateson P, Barker D, Clutton-Brock T, Deb D, D'Udine B, Foley RA, Gluckman P, Godfrey K, Kirkwood T, Lahr MM, McNamara, C.J., Metcalfe NB, Monaghan P, Spencer HG, Sultan SE (2004) Developmental plasticity and human health. Nature 430:419-421

Battista MC, Oligny LL, St-Louis J, Brochu M (2002) Intrauterine growth restriction in rats is associated with hypertension and renal dysfunction in adulthood. Am J Physiol 283:E124-E131

Baylis C (1994) Glomerular filtration and volume regulation in gravid animal models. Baillieres Clin Obstet Gynaecol 8:235-264

Baylis C, Rennke HG (1985) Renal hemodynamics and glomerular morphology in repetitively pregnant aging rats. Kidney Int 28:140-145 
Bell AW, Bauman DE (1997) Adaptations of glucose metabolism during pregnancy and lactation. J Mammary Gland Biol Neoplasia 2:265-278

Bellamy L, Casas J, Hingorani AD, Williams DJ (2007) Pre-eclampsia and risk of cardiovascular disease and cancer in later life: systematic review and meta-analysis. Br Med J 7627:974-977

Benyshek DC, Johnston CS, Martin JF (2006) Glucose metabolism is altered in the adequatelynourished grand-offspring ( $\mathrm{F} 3$ generation) of rats malnourished during gestation and perinatal life. Diabetologia 49:1117-1119

Berghella V (2007) Prevention of recurrent fetal growth restriction. Obstet Gynecol 110:904-912

Bertram C, Khan O, Ohri S, Phillips DI, Matthews SG, Hanson MA (2008) Transgenerational effects of prenatal nutrient restriction on cardiovascular and hypothalamic-pituitary-adrenal function. J Physiol 586:2217-2229

Blondeau B, Garofano A, Czernichow P, Breant B (1999) Age-dependent inability of the endocrine pancreas to adapt to pregnancy: a long-term consequence of perinatal malnutrition in the rat. Endocrinology 140:4208-4213

Bone AJ, Taylor KW (1976) Metabolic adaptation to pregnancy shown by increased biosynthesis of insulin in islets of Langerhans isolated from pregnant rat. Nature 262:501-502

Bubb KJ, Cock ML, Black J, Dodic M, Boon WM, Parkington HC, Harding R, Tare M (2007) Intrauterine growth restriction delays cardiomyocyte maturation, and alters coronary artery function in the fetal sheep. J Physiol 578:871-881

Buchbinder A, Sibai BM, Caritis S, Macpherson C, Hauth J, Linheimer MD, Klebanoff M, Vandorsten P, Landon M, Paul R, Miodovnik M, Meis P, Thurnau G (2002) Adverse perinatal outcomes are significantly higher in severe gestational hypertension than in mild preeclampsia. Am J Obstet Gynecol 186:66-71

Burdge GC, Slater-Jefferies J, Torrens C, Phillips ES, Hanson MA, Lillycrop KA (2007) Dietary protein restriction of pregnant rats in the $\mathrm{F} 0$ generation induces altered methylation of hepatic gene promoters in the adult male offspring in the F1 and F2 generations. Br J Nutr 97:435-439

Butte NF (2000) Carbohydrate and lipid metabolism in pregnancy: normal compared with gestational diabetes mellitus. Am J Clin Nutr 71:1256S-1261S

Camm EJ, Martin-Gronert MS, Wright NL, Hansell JA, Ozanne SE, Giussani DA (2011) Prenatal hypoxia independent of undernutrition promotes molecular markers of insulin resistance in adult offspring. FASEB J 25:420-427

Carr DB, Newton KM, Utzschneider KM, Tong J, Gerchman F, Kahn SE, Heckbert SR (2008) Modestly elevated glucose levels during pregnancy are associated with a higher risk of future diabetes among women without gestational diabetes mellitus. Diabetes Care 31:1037-1039

Cawley RH, McKeown T, Record RG (1954) Parental stature and birth weight. Am J Hum Genet 6:448-456

Champagne FA, Weaver ICG, Diorio J, Dymov S, Szyf M, Meaney MJ (2006) Maternal care associated with methylation of the estrogen receptor-alb promoter and estrogen receptor-a expression in the medial preoptic area of female offspring. Endocrinology 147:2909-2915 
Chen Y, Chenier I, Tran S, Scotcher M, Chang S, Zhang S (2010) Maternal diabetes programs hypertension and kideny injury in offspring. Pediatr Nephrol 25:1319-1329

Clark SL, Cotton DB, Lee W, Bishop C, Hill T, Southwick J, Pivarnik J, Spillman T, DeVore GR, Phelan J, . (1989) Central hemodynamic assessment of normal term pregnancy. Am J Obstet Gynecol 161:1439-1442

Constantine MM, Ghulmiyyah LM, Tamayo E (2008) Transgenerational effect of fetal programming on vascular phenotype and reactivity in endothelial nitric oxide synthase knockout mouse model. Am J Obstet Gynecol 199:250-257

Dabelea D, Hanson RL, Lindsay RS, Pettitt DJ, Imperatore G, Gabir MM, Roumain J, Bennett PH, Knowler WC (2000) Intrauterine exposure to diabetes conveys risks for type 2 diabetes and obesity. A study of discordant sibships. Diabetes 49:2208-2211

Dahri S, Snoeck A, Reusens-Billen B, Remacle C, Hoet JJ (1991) Islet function in offspring of mothers on low-protein diet during gestation. Diabetes 40:115-120

Danielson LA, Conrad KP (1995) Acute blockade of nitric oxide synthase inhibits renal vasodilation and hyperfiltration during pregnancy in chronically instrumented conscious rats. J Clin Invest 96:482-490

Danielson LA, Kercher LJ, Conrad KP (2000) Impact of gender and endothelin on renal vasodilation and hyperfiltration induced by relaxin in conscious rats. Am J Physiol 279:R1298R1304

Davison JM (1985) The effect of pregnancy on kidney function in renal allograft recipients. Kidney Int 27:74-79

De Blasio MJ, Gatford KL, McMillen IC, Robinson JS, Owens JA (2007) Placental restriction of fetal growth increases insulin action, growth and adiposity in the young lamb. Endocrinology 148:1350-1358

Drake AJ, Walker BR (2004) The intergenerational effects of fetal programming: non-genomic mechanisms for the inheritance of low birth weight and cardiovascular risk. J Endocrinol 180:1-16

Drake AJ, Walker BR, Seckl JR (2005) Intergenerational consequences of fetal programming by in utero exposure to glucocorticoids in rats. Am J Physiol 288:34-38

Dugani CB, Klip A (2005) Glucose transporter 4: cycling, compartments and controversies. EMBO Rep 6:1137-1142

Emanuel I, Filakti H, Alberman E, Evans SJ (1992) Intergenerational studies of human birthweight from the 1958 birth cohort. 1. Evidence for a multigenerational effect. Br J Obstet Gynaecol 99:6774

Eriksson J, Forsen T, Tuomilehto J, Osmond C, Barker D (2000) Fetal and childhood growth and hypertension in adult life. Hypertens 36:790-794

Eriksson JG, Forsén T, Tuomilehto J, Osmond C, Barker DJP (2001) Early growth and coronary heart disease in later life: longitudinal study. Br Med J 322:948-953

Feig DS, Zinman B, Wang X, Hux JE (2008) Risk of development of diabetes mellitus after diagnosis of gestational diabetes. CMAJ 179:229-234 
Fernandez-Twinn DS, Ozanne SE, Ekizoglou S, Doherty C, James L, Gusterson B, Hales CN (2003) The maternal endocrine environment in the low-protein model of intra-uterine growth restriction. Br J Nutr 90:815-822

Fowden AL, Hill DJ (2001) Intra-uterine programming of the endocrine pancreas. Brit Med Bull 60:123-142

Frantz EDC, Aguila MB, Pinheiro-Mulder ADR, Mandarim-de-Lacerda CA (2011) Transgenerational endocrine pancreatic adpatation in mice from maternal protein restriction in utero. Mech Ageing Dev 132:110-116

Friedlander Y, Paltiel O, Manor O, Deutsch L, Yanetz R, Calderon-Margalit R, Siscovick DS, Harlap S (2007) Birthweight of offspring and mortality of parents: the Jerusalem perinatal study cohort. Ann Epidemiol 17:914-922

Fu Q, McKnight RA, Yu X, Wang L, Callaway CW, Lane RH (2004) Uteroplacental insufficiency induces site-specific changes in histone $\mathrm{H} 3$ covalent modifications and affects DNA-histone H3 positioning in day 0 IUGR rat liver. Physiol Genomics 20:108-116

Gallo LA, Tran M, Moritz KM, Mazzuca MQ, Parry LJ, Westcott KT, Jefferies AJ, CullenMcEwen LA, Wlodek ME (2012) Cardio-renal and metabolic adaptations during pregnancy in female rats born small: implications for maternal health and second generation fetal growth. J Physiol 590:617-630

Gandley RE, Conrad KP, McLaughlin MK (2001) Endothelin and nitric oxide mediate reduced myogenic reactivity of small renal arteries from pregnant rats. Am J Physiol 280:R1-R7

Garofano A, Czernichow P, Breant B (1997) In utero undernutrition impairs rat beta-cell development. Diabetologia 40:1231-1234

Garovic VD, Bailey KR, Boerwinkle E, Hunt SC, Weder AB, Curb D, Mosley JHJ, Wiste HJ, Turner ST (2010) Hypertension in pregnancy as a risk factor for cardiovascular disease later in life. J Hypertens 28:826-833

Gatford KL, Mohammad SNB, Harland ML, De Blasio MJ, Fowden AL, Robinson JS, Owens JA (2008) Impaired b-cell function and inadequate compensatory increases in b-cell mass following intrauterine growth restriction in sheep. Endocrinology 149:5118-5127

Gluckman PD, Hanson MA, Spencer HG, Bateson P (2005) Environmental influences during development and their later consequences for health and disease: implications for the interpretations of empirical studies. Proc R Soc Biol 272:671-677

Granger JP (2002) Maternal and fetal adaptations during pregnancy: lessons in regulatory and integrative physiology. Am J Physiol 283:R1289-R1292

Gunderson EP, Chiang V, Lewis CE, Catov J, Queensberry CPJr, Sidney S, Wei GS, Ness R (2008) Long-term blood pressure changes measured from before to after pregnancy relative to nonparous women. Obstet Gynecol 112:1294-1302

Gunderson EP, Jacobs Jr DR, Chiang V, Lewis CE, Tsai A, Quesenberry Jr CP (2009) Childbearing is associated with higher incidence of the metabolic syndrome among women of reproductive age controlling for measurments before pregnancy: the CARDIA study. Am J Obstet Gynecol 201:177.e1-9 
Gunderson EP, Murtaugh MA, Lewis CE, Quesenberry CP, West DS, Sidney D (2004) Excess gains in weight and waist circumference associated with childbearing: The Coronary Artery Risk Development in Young Adults Study (CARDIA). Int J Obes 28:525-535

Hales CN, Barker DJ, Clark PM, Cox LJ, Fall C, Osmond C, Winter PD (1991) Fetal and infant growth and impaired glucose tolerance at age 64. Br Med J 303:1019-1022

Hales CN, Barker DJP (1992) Type 2 (non-insulin-dependent) diabetes mellitus: the thrifty phenotype hypothesis. Diabetologia 35:595-601

Hallan S, Euser AM, Irgens LM, Finken MJ, Holmen J, Dekker FW (2008) Effect of intrauterine growth restriction on kidney function at young adult age: the Nord Trondelag Health (HUNT 2) Study. Am J Kidney Dis 51:10-20

Harrison M, Langley-Evans SC (2009) Intergenerational programming of impaired nephrogenesis and hypertension in rats following maternal protein restriction during pregnancy. $\mathrm{Br} \mathrm{J}$ Nutr 101:1020-1030

Heijmans BT, Tobi EW, Stein AD, Putter H, Blauw Gj, Susser ES, Slagboom PE, Lumey LH (2008) Persistent epigenetic diffeences associated with prenatal exposure to famine in humans. PNAS 105:17046-17049

Hemmings DG, Veerareddy S, Baker PN, Davidge ST (2005) Increased myogenic responses in uterine but not mesenteric arteries from pregnant offspring of diet-restricted rat dams. Biol Reprod 72:997-1003

Henriksen T, Clausen T (2002) The fetal origins hypothesis: placental insufficiency and inheritance versus maternal malnutrition in well-nourished populations. Acta Obstet Gynecol Scand 81:112-114

Hermann TS, Rask-Madsen C, Ihlemann N, Domínguez H, Jensen CB, Storgaard H, Vaag AA, Kober L, Torp-Pedersen C (2003) Normal insulin-stimulated endothelial function and impaired insulin-stimulated muscle glucose uptake in young adults with low birth weight. J Clin Endocrinol Metab 88:1252-1257

Herrera E (2000) Metabolic adaptations in pregnancy and their implications for the availability of substrates to the fetus. Eur J Clin Nutr 54 Suppl 1:S47-S51

Hill CC, Pickinpaugh J (2008) Physiologic changes in pregnancy. Surg Clin North Am 88:391-401, vii

Hill DJ, Duvillie B (2000) Pancreatic development and adult diabetes. Pediatr Res 48:269-274

Hinchliffe SA, Lynch MR, Sargent PH, Howard CV, Van Velzen D (1992) The effect of intrauterine growth retardation on the development of renal nephrons. Br J Obstet Gynaecol 99:296301

Hines T (2000) Baroreceptor afferent discharge in the pregnant rat. Am J Physiol 278:R1433-R1440

Holemans K, Gerber R, Meurrens K, De Clerck F, Poston L, Van Assche FA (1999) Maternal food restriction in the second half of pregnancy affects vascular function but not blood pressure of rat female offspring. Br J Nutr 81:73-79 
Hoppe CC, Evans RG, Moritz KM, Cullen-McEwen LA, Fitzgerald SM, Dowling J, Bertram JF (2007) Combined prenatal and postnatal protein restriction influences adult kidney structure, function, and arterial pressure. Am J Physiol 292:R462-R469

Hoy WE, Hughson MD, Signh GR, Douglas-Denton R, Bertram JF (2006) Reduced nephron number and glomerulomegaly in Australian Aborigines: a group at high risk for renal disease and hypertension. Kidney Int 70:104-110

Hoy WE, Rees M, Kile E, Mathews JD, Wang Z (1999) A new dimension to the Barker hypothesis: low birthweight and susceptibility to renal disease. Kidney Int 56:1072-1077

Huda SS, Brodie LE, Sattar N (2009) Obesity in pregnancy: prevalence and metabolic consequences. Semin Fetal Neonatal Med

Hughson M, Farris AB, Douglas-Denton R, Hoy WE, Bertram JF (2003) Glomerular number and size in autopsy kidneys: the relationship to birth weight. Kidney Int 63:2113-2122

Hughson MD, Douglas-Denton R, Bertram JF, Hoy WE (2006) Hypertension, glomerular number, and birth weight in African Americans and white subjects in the southeastern United States. Kidney Int 69:671-678

Hytten FE, Leitch I (1971) The Physiology of Human Pregnancy. Oxford; Blackwell Scientific,

Ibanez L (2000) Reduced uterine and ovarian size in adolescent girls born small for gestational age. Pediatr Res 47:575-577

Irgens HU, Reisaeter L, Irgens LM, Lie RT (2001) Long term mortality of mothers and fathers after pre-eclampsia: population based cohort study. Br Med J 323:1213-1217

Jablonka E, Raz G (2009) Transgenerational epigenetic inheritance: prevalence, mechanisms, and implications for the study of heredity and evolution. Q Rev Biol 84:131-176

Jaquet D, Vidal H, Hankard R, Czernichow P, Levy-Marchal C (2001) Impaired regulation of glucose transporter 4 gene expression in insulin resistance associated with in utero undernutrition. $\mathrm{J}$ Clin Endocrinol Metab 86:3266-3271

Jaquiery AL, Oliver MH, Rumball CW, Bloomfield FH, Harding JE (2009) Undernutrition before mating in ewes impairs the development of insulin resistance during pregnancy. Obstet Gynecol 114:869-876

Jensen CB, Storgaard H, Dela F, Juul Holst J, Madsbad S, Vaag AA (2002) Early differential defects of insulin secretion and action in 19 year old caucasian men who had low birth weight. Diabetes 51:1271-1280

Jones DC, Hayslett JP (1996) Outcome of pregnancy in women with moderate or severe renal insufficiency. N Engl J Med 335:226-232

Kaati G, Bygren LO, Edvinsson S (2002) Cardiovascular and diabetes mortality determined by nutrition during parents' and grandparents' slow growth period. Eur J Hum Genet 10:682-688

Kawai M, Kishi K (1999) Adaptation of pancreatic islet B-cells during the last third of pregnancy: regulation of B-cell function and proliferation by lactogenic hormones in rats. Eur $\mathrm{J}$ Endocrinol $141: 419-425$ 
Klebanoff MA, Secher NJ, Mednick BR, Schulsinger C (1999) Maternal size at birth and the development of hypertension during pregnancy: a test of the Barker hypothesis. Arch Intern Med 159:1607-1612

Knopp RH, Herrera E, Freinkel N (1970a) Carbohydrate metabolism in pregnancy. 8. Metabolism of adipose tissue isolated from fed and fasted pregnant rats during late gestation. J Clin Invest 49:1438-1446

Knopp RH, Ruder HJ, Herrera E, Freinkel N (1970b) Carbohydrate metabolism in pregnancy. VII. Insulin tolerance during late pregnancy in the fed and fasted rat. Acta Endocrinol (Copenh) 65:352360

Kuhl C (1991) Aetiology of gestational diabetes. Baillieres Clin Obstet Gynaecol 5:279-292

Laker RC, Gallo LA, Wlodek ME, Siebel AL, Wadley GD, McConell GK (2011) Short-term exercise training early in life restores deficits in pancreatic b-cell mass associated with growth restriction in adult male rats. Am J Physiol 301:E931-E940

Lane RH, Flozak AS, Ogata ES, Bell GI, Simmons RA (1996) Altered Hepatic Gene Expression of Enzymes Involved in Energy Metabolism in the Growth Retarded Fetal Rat. Pediatr Res 39:390394

Lane RH, Maclennan NK, Hsu JL, Janke SM, Pham TD (2002) Increased hepatic peroxisome proliferator-activated receptor-gamma coactivator-1 gene expression in a rat model of intrauterine growth retardation and subsequent insulin resistance. Endocrinology 143:2486-2490

Law CM, De Swiet M, Osmond C, Fayers PM, Barker DJP, Cruddas AM, Fall CHD (1993) Initiation of hypertension in utero and its amplification throughout life. Br Med J 306:24-27

Lazinski MJ, Shea AK, Steiner M (2008) Effects of maternal prenatal stress on offspring development: a commentary. Arch Womens Ment Health 11:363-375

Leturque A, Burnol AF, Ferre P, Girard J (1984a) Pregnancy-induced insulin resistance in the rat: assessment by glucose clamp technique. Am J Physiol 246:E25-E31

Leturque A, Guerre-Millo M, Lavau M, Girard J (1984b) Effect of insulin on glucose metabolism in adipocytes from virgin and late-pregnant rats. Biochem J 224:685-688

Li S, Chen SC, Shlipak M, Bakris G, McCullough PA, Sowers J, Stevens L, Jurkovitz C, McFarlane S, Norris K, Vassalotti J, Klag MJ, Brown WW, Narva A, Calhoun D, Johnson B, Obialo C, Whaley-Connell A, Becker B, Collins AJ (2008) Low birth weight is associated with chronic kidney disease only in men. Kidney Int 73:637-642

Lindheimer MD, Davison JM, Katz AI (2001) The kidney and hypertension in pregnancy: twenty exciting years. Semin Nephrol 21:173-189

Lithell HO, McKeigue PM, Berglund L, Mohsen R, Lithell UB, Leon DA (1996) Relation of size at birth to non-insulin dependent diabetes and insulin concentrations in men aged 50-60 years. Br Med J 312:406-410

Lopez-Luna P, Munoz T, Herrera E (1986) Body fat in pregnant rats at mid- and late-gestation. Life Sci 39:1389-1393 
Lucas A (1991) Programming by early nutrition in man. In: Wiley J (ed) The childhood environment and adult disease. John Wiley \& Sons Ltd., Chichester, pp. 38-55

Luppi CJ (1999) Cardiopulmonary resuscitation in pregnancy. What all nurses caring for childbearing women need to know. AWHONN Lifelines 3:41-45

Lykke JA, Langhoff-Roos J, Lockwood CJ, Triche EW, Paidas MJ (2010) Mortality of mothers from cardiovascular and non-cardiovascular causes following pregnancy complications in first delivery. Paediatr Perinat Epidemiol 24:323-330

Manalich R, Reyes L, Herrera M, Melendi C, Fundora I (2000) Relationship between weight at birth and the number and size of renal glomeruli in humans: a histomorphometric study. Kidney Int 58:770-773

Martin JA, Hamilton BE, Sutton PD, Ventura SJ, Menacker F, Kimeyer S, Munson ML (2007) Births: Final Data for 2005. Natl Vital Stat Rep 56:

Mazzuca MQ, Tare M, Dragomir NM, Parkington HC, Wlodek ME (2009a) Late gestation uteroplacental insufficiency programs regional vascular dysfunction in non pregnant and pregnant growth restricted female offspring. JDOHaD 1:S51

Mazzuca MQ, Tare M, Parkington HC, Wlodek ME (2009b) Uteroplacental insufficiency programs region-specific vascular dysfunction in non pregnant and pregnant growth restricted offspring. $\mathrm{J}$ Paediatr Child Health 45:A40

Mazzuca MQ, Wlodek ME, Dragomir NM, Parkington HC, Tare M (2010) Uteroplacental insufficiency programs regional vascular dysfunction and alters arterial stiffness in female offspring. J Physiol 588:1997-2010

McCance DR, Pettitt DJ, Hanson RL, Jacobsson LTH, Knowler WC, Bennett PH (1994) Birth weight and non-insulin dependent diabetes: thrifty genotype, thrifty phenotype, or surviving small baby genotype? Br Med J 308:942-945

McMillen IC, Robinson JS (2005) Developmental origins of the metabolic syndrome: prediction, plasticity and programming. Physiol Rev 85:571-633

Merzouk H, Meghelli-Bouchenak M, Loukidi B, Prost J, Belleville J (2000) Impaired serum lipids and lipoproteins in fetal macrosomia related to maternal obesity. Biol Neonate 77:17-24

Metcalf J, Romney SL, Ramsey LH, Reid DE, Burcwell CS (1955) Estimation of uterine blood flow in normal human pregnancy at term. J Clin Invest 34:1632-1638

Moritz KM, Bertram JF (2006) Barker and Brenner: a basis for hypertension? Curr Hypertens Rev 2:179-185

Moritz KM, Mazzuca MQ, Siebel AL, Mibus A, Arena D, Tare M, Owens JA, Wlodek ME (2009) Uteroplacental insufficiency causes a nephron deficit, modest renal insufficiency but no hypertension with ageing in female rats. J Physiol 587:2635-2646

Munkhaugen J, Lydersen S, Romundstad PR, Wideroe TE, Vikse BE, Hallan S (2009) Kidney function and future risk for adverse pregnancy outcomes: a population-based study from HUNT II, Norway. Nephrol Dial Transplant 24:3744-3750 
Najarian JS, Chavers BM, McHugh LE, Matas AJ (1992) 20 years or more of follow-up of living kidney donors. Lancet 340:807-810

Nenov VD, Taal MW, Sakharova OV, Brenner BM (2000) Multi-hit nature of chronic renal disease. Curr Opin Nephrol Hypertens 9:85-97

Nissel H, Lintu H, Lunell NO, et al. (1995) Blood pressure and renal function seven years after pregnancy complicated by hypertension. Br J Obstet Gynaecol 102:876-881

Nolan CJ, Proietto J (1994) The feto-placental glucose steal phenomenon is a major cause of maternal metabolic adaptation during late pregnancy in the rat. Diabetologia 37:976-984

Nusken KD, Dotsch J, Rauh M, Rascher W, Schneider H (2008) Uteroplacental insufficiency after bilateral uterine artery ligation in the rat: impact on postnatal glucose and lipid metabolism and evidence for metabolic programming of the offspring by sham operation. Endocrinology 149:10561063

Oh W, Gelardi NL, Cha CJ (1991) The cross-generation effect of neonatal macrosomia in rat pups of streptozotocin-induced diabetes. Pediatr Res 29:606-610

Osmond C, Barker DJ, Winter PD, Fall CH, Simmonds SJ (1993) Early growth and death from cardiovascular disease in women. Br Med J 307:1519-1524

Owens JA, Gatford KL, De Blasio MJ, Edwards LJ, McMillen IC, Fowden AL (2007) Restriction of placental growth in sheep impairs insulin secretion but not sensitivity before birth. J Physiol 584:935-949

Ozanne SE, Jensen CB, Tingey KJ, Storgaard H, Madsbad S, Vaag AA (2005) Low birthweight is associated with specific changes in muscle insulin-signalling protein expression. Diabetologia 48:547-552

Ozanne SE, Olsen GS, Hansen LL, Tingey KJ, Nave BT, Wang CL, Hartil K, Petry CJ, Buckley AJ, Mosthaf-Seedorf L (2003) Early growth restriction leads to down regulation of protein kinase C zeta and insulin resistance in skeletal muscle. J Endocrinol 177:235-241

Ozanne SE, Wang CL, Petry CJ, Smith JM, Hales CN (1998) Ketosis resistance in the male offspring of protein-malnourished rat dams. Metabolism 12:1450-1454

Painter RC, Roseboom TJ, Bleker OP (2005) Prenatal exposure to the Dutch famine and disease in later life: an overview. Reprod Toxicol 20:345-352

Park JH, Stoffers DA, Nicholls RD, Simmons RA (2008) Development of type 2 diabetes following intrauterine growth retardation in rats is associated with progressive epigenetic silencing of Pdx1. J Clin Invest 118:2316-2324

Petry CJ, Dorling MW, Pawlak DB, Ozanne SE, Hales CN (2001) Diabetes in old male offspring of rat dams fed a reduced protein diet. Int J Exp Diabetes Res 2:139-143

Pham TD, Maclennan NK, Chiu CT, Laksana GS, Hsu JL, Lane RH (2003) Uteroplacental insufficiency increases apoptosis and alters p53 gene methylation in the full-term IUGR rat kidney. Am J Physiol 285:R962-R970

Phillips DI (1996) Insulin resistance as a programmed response to fetal undernutrition. Diabetologia 39:1119-1122 
Phillips DI, Barker DJ, Hales CN, Hirst S, Osmond C (1994) Thinness at birth and insulin resistance in adult life. Diabetologia 37:150-154

Phipps K, Barker DJ, Hales CN, Fall CH, Osmond C, Clark PM (1993) Fetal growth and impaired glucose tolerance in men and women. Diabetologia 36:225-228

Ramakrishnan U, Martorell R, Schroeder DG, Flores R (1999) Role of intergenerational effects on linear growth. J Nutr 129:544S-549S

Ramcharan T, Matas AJ (2002) Long-term (20-37 years) follow-up of living kidney donors. Am J Transplant 2:959-964

Ramin SM, Vidaeff AC, Yeomans ER, Gilstrap LC, III (2006) Chronic renal disease in pregnancy. Obstet Gynecol 108:1531-1539

Ravelli ACJ, Van Der Meulen JHP, Michels RPJ, Osmond C, Barker DJP, Hales CN, Bleker OP (1998) Glucose tolerance in adults after prenatal exposure to famine. Lancet 351:173-177

Ravelli G, Stein ZA, Susser MW (1976) Obesity in young men after famine exposure in utero and early infancy. N Engl J Med 295:349-353

Retnakaran R (2009) Glucose tolerance status in pregnancy: a window to the future risk of diabetes and cardiovascular disease in young women. Curr Diabetes Rev 5:239-244

Retnakaran R, Qi Y, Sermer M, Connelly PW, Hanley AJ, Zinman B (2008) Glucose intolerance in pregnancy and future risk of pre-diabetes or diabetes. Diabetes Care 31:2026-2031

Robinson JS, Kingston EJ, Jones CT, Thorburn GD (1979) Studies on experimental growth retardation in sheep. The effect of removal of a endometrial caruncles on fetal size and metabolism. J Dev Physiol 1:379-398

Roseboom TJ, Van Der Meulen JHP, Ravelli ACJ, Osmond C, Barker DJP, Bleker OP (2001) Effects of prenatal exposure to the dutch famine on adult disease in later life: an overview. Mol Cell Endocrinol 185:93-98

Rosenfeld CR (2001) Mechanisms regulating angiotensin II responsiveness by the uteroplacental circulation. Am J Physiol 281:R1025-R1040

Rueda-Clausen CF, Dolinsky VW, Morton JS, Proctor SD, Dyck JRB, Davidge ST (2011) Hypoxia-induced intrauterine growth restriction increases the susceptibility of rats to high-fat dietinduced metabolic syndrome. Diabetes 60:507-540

Rumball CW, Bloomfield FH, Oliver MH, Harding JE (2009) Different periods of periconceptional undernutrition have different effects on growth, metabolic and endocrine status in fetal sheep. Pediatr Res 66:605-613

Saad MJ, Maeda L, Brenelli SL, Carvalho CR, Paiva RS, Velloso LA (1997) Defects in insulin signal transduction in liver and muscle of pregnant rats. Diabetologia 40:179-186

Sanders MW, Fazzi GE, Janssen GM, De Leeuw PW, Blanco CE, De Mey JG (2004) Reduced uteroplacental blood flow alters renal arterial reactivity and glomerular properties in the rat offspring. Hypertens 43:1283-1289 
Sathyapalan T, Mellor D, Atkin SL (2009) Obesity and gestational diabetes. Semin Fetal Neonatal Med 15:89-93

Sattar N (2004) Do pregnancy complications and CVD share common antecedents? Atheroscler Suppl 5:3-7

Sattar N, Ramsay J, Crawford L, Cheyne H, Greer IA (2003) Classic and novel risk factor parameters in women with a history of preeclampsia. Hypertens 42:39-42

Seghieri G, Anichini R, De Bellis A, Alviggi L, Franconi F, Breschi MC (2002) Relationship between gestational diabetes mellitus and low maternal birth weight. Diabetes Care 25:1761-1765

Shulman GI (2000) Cellular mechanisms of insulin resistance. J Clin Invest 106:171-176

Siebel AL, Gallo LA, Guan TC, Owens JA, Wlodek ME (2010) Cross-fostering and improved lactation ameliorates deficits in endocrine pancreatic morphology in growth restricted adult male rat offspring. JDOHaD 1:234-244

Siebel AL, Mibus A, De Blasio MJ, Westcott KT, Morris MJ, Prior L, Owens JA, Wlodek ME (2008) Improved lactational nutrition and postnatal growth ameliorates impairment of glucose tolerance by uteroplacental insufficiency in male rat offspring. Endocrinology 149:3067-3076

Simmons RA, Templeton LJ, Gertz SJ (2001) Intrauterine growth retardation leads to the development of type 2 diabetes in the rat. Diabetes 50:2279-2286

Smith GC, Pell JP, Walsh D (2001) Pregnancy complications and maternal risk of ischaemic heart disease: a retrospective cohort study of 129,290 births. Lancet 357:2002-2006

Snoeck A, Remacle C, Reusens B, Hoet JJ (1990) Effect of low protein diet during pregnancy on the fetal rat endocrine pancreas. Biol Neonate 57:107-118

Stanner SA, Yudkin JS (2001) Fetal programming and the Leningrad Siege study. Twin Res 4:287292

Thamotharan M, Garg M, Oak S, Rogers LM, Pan G, Sangiorgi F, Lee PWN, Devaskar SU (2007) Transgenerational inheritance of the insulin-resistant phenotype in embryo-transferred intrauterine growth-restricted adult female rat offspring. Am J Physiol 292:E1270-E1279

Thamotharan M, Shin BC, Suddirikku DT, Thamotharan S, Garg M, Devaskar SU (2005) GLUT4 expression and subcellular localization in the intrauterine growth-restricted adult rat female offspring. Am J Physiol 288:E935-E947

Todd SE, Oliver MH, Jaquiery AL, Bloomfield FH, Harding JE (2009) Periconceptional undernutrition of ewes impairs glucose tolerance in their adult offspring. Pediatr Res 65:409-413

Torgersen KL, Curran CA (2006) A systematic approach to the physiologic adaptations of pregnancy. Crit Care Nurs Q 29:2-19

Torrens C, Brawley L, Barker AC, Itoh S, Poston L, Hanson MA (2003) Maternal protein restriction in the rat impairs resistance artery but not conduit artery function in pregnant offspring. $\mathrm{J}$ Physiol 547:77-84 
Torrens C, Poston L, Hanson MA (2008) Transmission of raised blood pressure and endothelial dysfunction to the $\mathrm{F} 2$ generation induced by maternal protein restriction in the $\mathrm{F} 0$, in the absence of dietary challenge in the F1 generation. Br J Nutr 100:760-766

Van Assche FA, De Prins F, Aerts L, Verjans M (1977) The endocrine pancreas in small-for-date infants. Br J Obstet Gynaecol 84:751-753

Van Assche FA, Holemans K, Aerts L (2001) Long-term consequences for offspring of diabetes during pregnancy. Br Med Bull 60:173-182

Vehaskari VM, Aviles DH, Manning J (2001) Prenatal programming of adult hypertension in the rat. Kidney Int 59:238-245

Vikse BE, Irgens LM, Leivestad T, Skjaerven R, Iversen BM (2008) Preeclampsia and the risk of end-stage renal disease. N Engl J Med 359:800-809

Villar J, Cogswell M, Kestler E, Castillo P, Menendez R, Repke JT (1992) Effect of fat and fat-free mass deposition during pregnancy on birth weight. Am J Obstet Gynecol 167:1344-1352

Vuguin PM (2007) Animal models for small for gestational age and fetal programming of adult disease. Horm Res 68:113-123

Wadley GD, Siebel AL, Cooney GJ, McConell GK, Wlodek ME, Owens JA (2008) Uteroplacental insufficiency and reducing litter size alters skeletal muscle mitochondrial biogenesis in a sex specific manner in the adult rat. Am J Physiol 294:E861-E869

Walker BR, McConnachie A, Noon JP, Webb DJ, Watt GC (1998) Contribution of parental blood pressures to association between low birth weight and adult high blood pressure: cross sectional study. Br Med J 316:834-837

Welberg LAM, Thrivikraman KV, Plotsky PM (2005) Chronic maternal stress inhibits the capacity to up-regulate placental 11b-hydroxysteroid dehydrogenase type 2 activity. J Endocrinol 186:R7R12

White SL, Perkovic V, Cass A, Chang CL, Poulter NR, Spector T, Haysom L, Craig JC, Salmi IA, Chadban SJ, Huxley RR (2009) Is low birth weight an antecedent of CKD in later life? A systematic review of observational studies. Am J Kidney Dis 54:248-261

Wigglesworth JS (1974) Fetal growth retardation. Animal model: uterine vessel ligation in the pregnant rat. Am J Pathol 77:347-350

Wlodek ME, Mibus A, Tan A, Siebel AL, Owens JA, Moritz KM (2007) Normal lactational environment restores nephron endowment and prevents hypertension after placental restriction in the rat. J Am Soc Nephrol 18:1688-1696

Wlodek ME, Westcott K, Siebel AL, Owens JA, Moritz KM (2008) Growth restriction before or after birth reduces nephron number and increases blood pressure in male rats. Kidney Int 74:187195

Wlodek ME, Westcott KT, O'Dowd R, Serruto A, Wassef L, Moritz KM, Moseley JM (2005) Uteroplacental restriction in the rat impairs fetal growth in association with alterations in placental growth factors including PTHrP. Am J Physiol 288:R1620-R1627 
Woodall SM, Johnston BM, Breier BH, Gluckman PD (1996) Chronic maternal undernutrition in the rat leads to delayed postnatal growth and elevated blood pressure of offspring. Pediatr Res 40:438-443

Woods LL, Ingelfinger JR, Nyengaard JR, Rasch R (2001) Maternal protein restriction suppresses the newborn renin-angiotensin system and programs adult hypertension in rats. Pediatr Res 49:460467

Woods LL, Weeks DA, Rasch R (2004) Programming of adult blood pressure by maternal protein restriction: role of nephrogenesis. Kidney Int 65:1339-1348

Wu G, Bazer FW, Wallace JM, Spencer TE (2006) Board-invited review: intrauterine growth retardation: implications for the animal sciences. J Anim Sci 84:2316-2337

Yeomans ER, Gilstrap LC, III (2005) Physiologic changes in pregnancy and their impact on critical care. Crit Care Med 33:S256-S258

Zambrano E, Martinez-Samayoa PM, Bautista CJ, Deas M, Guillen L, Rodriguez-Gonzalez GL, Guzman C, Larrea F, Nathanielsz PW (2005) Sex differences in transgenerational alterations of growth and metabolism in progeny $(\mathrm{F} 2)$ of female offspring $(\mathrm{F} 1)$ of rats fed a low protein diet during pregnancy and lactation. J Physiol 566:225-236

Zetterström K, Lindeberg S, Haglund B, Magnuson A, Hanson U (2007) Being born small for gestational age incraeses the risk of severe pre-eclampsia. J Obstet Gynaecol 114:319-324

Zimanyi MA, Bertram JF, Black MJ (2004) Does a nephron deficit in rats predispose to saltsensitive hypertension? Kidney Blood Press R 27:239-247

Zohdi V, Moritz KM, Bubb KJ, Cock ML, Wreford N, Harding R, Black MJ (2007) Nephrogenesis and the renal renin-angiotensin system in fetal sheep: effects of intrauterine growth restriction during late gestation. Am J Physiol 293:R1267-R1273 
Manuscript No. CTR-12-0027.R1

Title : Maternal adaptations and inheritance in the transgenerational programming of adult disease

By: Gallo, Linda; Tran, Melanie; Master, Jordanna; Moritz, Karen; Wlodek, Mary

Manuscript Type: Special Issue Review

Instructions for figures:

Fig.1 $\quad 12.9 \mathrm{~cm}$

Fig.2 $\quad 12.9 \mathrm{~cm}$ 


\section{University Library}

\section{- M M N E R VA A gateway to Melbourne's research publications}

Minerva Access is the Institutional Repository of The University of Melbourne

Author/s:

Gallo, LA;Tran, M;Master, JS;Moritz, KM;Wlodek, ME

Title:

Maternal adaptations and inheritance in the transgenerational programming of adult disease

Date:

2012-09-01

Citation:

Gallo, L. A., Tran, M., Master, J. S., Moritz, K. M. \& Wlodek, M. E. (2012). Maternal adaptations and inheritance in the transgenerational programming of adult disease. CELL AND TISSUE RESEARCH, 349 (3), pp.863-880. https://doi.org/10.1007/s00441-012-1411-y.

Persistent Link:

http://hdl.handle.net/11343/282915 